\title{
Milton Friedman and U.S. Monetary History: 1961-2006
}

\author{
Edward Nelson
}

\begin{abstract}
This paper, using extensive archival material from several countries, brings together scattered information about Milton Friedman's views and predictions regarding U.S. monetary policy developments after 1960 (i.e., the period beyond that covered by his and Anna Schwartz's Monetary History of the United States). The author evaluates these interpretations and predictions in light of subsequent events. (JEL E31, E51, E52, E58)
\end{abstract}

Federal Reserve Bank of St. Louis Review, May/June 2007, 89(3), pp. 153-82.

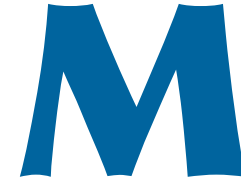

ilton Friedman and Anna J. Schwartz's (1963) A Monetary History of the United States covered a 93-year period: 1867 to 1960. Milton Friedman lived until November 2006 - 46 years beyond the period covered by the Monetary History and a length of time equal to nearly half that covered in that book. Throughout 1961-2006, Friedman commented publicly on U.S. monetary policy developments. This paper attempts to provide a perspective on Friedman's account of 1961-2006 U.S. monetary history by studying the observations he provided over that period.

Friedman provided no single detailed assessment of post-1960 U.S. monetary developments. Though Paul Samuelson once speculated of a time when "Milton Friedman and Anna Schwartz come to write their history of the crimes of 1974 and 1975" (NYT, 02/26/75), ${ }^{1}$ the Monetary History was the single volume of monetary history

1 In this paper, newspaper and magazine articles are cited in the text with their abbreviation and date. A key to the abbreviations is given in Appendix A, and Appendix B gives the newspaper articles referenced in chronological order. produced by the two authors; Friedman and Schwartz's subsequent collaborations were not a continuation of their historical analysis. ${ }^{2}$ Friedman (1984a) did provide a capsule history of monetary developments from 1960 to 1983; but not only did this study ultimately cover only one half of the post-1960 period through which Friedman lived, but Friedman's own views of 1979-83 developments underwent major revision in the years after 1984. There is thus no single definitive record by Friedman available of his version of events. But major elements of it can be recovered, as there are many forums to which he contributed over this period that contain his observations on contemporary monetary policy. I therefore study Friedman's account of 1961-2006 using a variety of sources: not only Friedman's post-

2 In particular, Friedman and Schwartz's (1982) Monetary Trends has "1867-1975" in its title but is not an update of the monetary history to 1975; rather, the authors offered a "statistical and theoretical analysis" to complement the "chronological and largely qualitative analysis" of the Monetary History (Friedman and Schwartz, 1982, p. xxviii). Consistent with this, Friedman and Schwartz (1982) mention Arthur Burns several times, but it is always with reference to Burns's scholarly work on business fluctuations and never with reference to his position as Federal Reserve Chairman from 1970 onward.

Edward Nelson is an assistant vice president and economist at the Federal Reserve Bank of St. Louis. The author thanks Richard Anderson, Mario Crucini, Amit Kara, David Laidler, Anna Schwartz, and David Wheelock for comments on an earlier draft of this paper. Justin Hauke provided research assistance, and Kathy Cosgrove, Marc Giannoni, Katrina Stierholz, Julia Williams, and Andreas Worms assisted with recovering archival material.

(C) 2007, The Federal Reserve Bank of St. Louis. Articles may be reprinted, reproduced, published, distributed, displayed, and transmitted in their entirety if copyright notice, author name(s), and full citation are included. Abstracts, synopses, and other derivative works may be made only with prior written permission of the Federal Reserve Bank of St. Louis. 
1960 writings on monetary affairs, but other public statements he gave in media interviews, speeches, and congressional testimony. This broad source base includes-over and above Friedman's contributions to books, journals, and media-reporting on Friedman's public statements that appeared in newspapers and magazines in the United States, the United Kingdom, Australia, Canada, Germany, Hong Kong, Ireland, Israel, New Zealand,

Singapore, and South Africa. ${ }^{3}$

My discussion moves between material drawn from Friedman's statements in the media and material from his contributions to specialist monetary economics outlets. This approach might be questioned. Friedman's critics have sometimes argued that Friedman's economic analysis was not consistent across his technical and popular writings. In particular, they alleged that Friedman used a harder-line and more mechanical version of monetarism in his journalism. This criticism, first made by Paul Samuelson and James Tobin, has recently been revived by Krugman (2007a). ${ }^{4}$ In my view, however, the criticism is without merit. Friedman (1970a, 1972a) provided detailed examples showing that the monetary analysis in his popular writings was consistent with that in his technical work, and this judgment has been affirmed by Gordon (1976) and Nelson (2004). More recently, Schwartz and Nelson (2007) provide a rebuttal to Krugman (2007a) on this issue.

\section{CRITIC OF MONETARY POLICY: 1961-68}

The London Financial Times in late 1962 referred to "Americans' surprising addiction to pre-Keynesian economics” (FT, 12/29/62), a remark undoubtedly inspired by the U.S. economic policy record of the 1950s. That period

\footnotetext{
3 Previous studies of Friedman's contribution to policy debates include Frazer (1988), Hammond (1996), Leeson (2000), and Nelson (2004). Due to my expanded base of source material and my focus on U.S. monetary history, the overlap here with those studies is minor.

4 The earlier articulations of this argument appeared in Tobin (1970) and a 1968 commentary by Samuelson (STE, 12/15/68).
}

was characterized, in addition to fiscal conservatism, by a monetary policy directed at restraint on aggregate demand, as Romer and Romer (2002) show. Romer and Romer provide evidence, based on documentary material and policy-rule estimates, that U.S. monetary policy had a modern inflation-oriented outlook-one acknowledged, albeit pejoratively, by Paul Samuelson in 1965 when he referred to the Federal Reserve's "antiinflation paranoia of the 1950s" (FT, 12/31/65).

Romer and Romer (2002, p. 121) argue that Milton Friedman did not judge 1950s monetary policy favorably. This understates Friedman's praise of 1950s monetary policy, both in the Monetary History with Schwartz and subsequently. Though a critic of the Federal Reserve's overall record since its inception, Friedman praised the mid- and late-1950s policy of "restraint... [which] eliminated inflation by 1960." Friedman and Schwartz (1963, p. 628) had praised the "nearrevolutionary change" in official statements in 1952-54 toward acknowledging the importance of the money supply, and in 1965 Friedman suggested that the Federal Reserve's attention to money supply data during 1959-60 helped stop the recession of 1960-61 from being worse. ${ }^{6}$ Friedman argued that a large part of the credit for the anti-inflationary monetary policy of the 1950s was due to the Eisenhower Administration, for showing solidarity with the Federal Reserve and resisting the "temper of the time" that favored aggressive stimulation of aggregate demand ( $N W$, 12/06/76). The burying of inflationary expectations by the early 1960s, Friedman contended, resulted from "the [economic] slowdown that $\mathrm{Mr}$. Eisenhower was willing to accept at the end of the 1950s" (CHA, 11/73).

While applauding the price stability that the monetary policy of the late 1950s had produced, Friedman felt that a steadier policy, involving fewer fluctuations of money growth around its downward trend, could have generated the same result. Actual policy, he believed, had worsened business cycle fluctuations by ill-timed finetuning. Thus the 1950s were not excluded from

\footnotetext{
5 Friedman (1984a, p. 26).

6 See Friedman (1968a, p. 146).
} 
(i) his generalization in 1967 that " $[\mathrm{t}]$ hroughout the post-war period...the Fed has tended first to delay action and then, when it did act, to go too far" $(N W, 10 / 30 / 67)$ or (ii) his statement in 1964 that "we ought to convert monetary policy from being a destabilizing force into at least being a neutral factor."7

Monetary policy, already expansionary from mid-1960, became more so from 1961, with both the Kennedy Administration and the Federal Reserve supporting stimulation of the economy. This monetary expansion is evident in an increase in money growth (using today's M1 and M2 definitions) during the first half of the 1960s. Most of the shift to a higher growth rate was completed in 1961, with money growth in the succeeding years quite smooth. That smoothness, Friedman suggested, was why the United States avoided a recession after $1960 .^{8}$ Friedman developed this theme in an October 1965 consultant's memorandum to the Board of Governors, which noted that in the prior three years "monetary growth has been relatively stable by past standards," an "excellent" monetary policy performance. ${ }^{9}$ Consistent with his 1965 judgment, Friedman came to regard the early-to-mid 1960s as testament to the value of stable monetary growth; in 1977, for example, he calculated that the standard deviation of M2 growth for 1963:Q3-1966:Q4 was close to the lowest observed in the postwar era for any period of comparable length. ${ }^{10}$

Friedman served as economic advisor to Republican candidate Barry Goldwater during the 1964 presidential election campaign. Goldwater eventually suffered a landslide defeat to President Lyndon Johnson. Friedman's monetary policy proposals were not likely to be implemented even if Goldwater had won, as Goldwater had already said that a constant money growth rule "would require too fundamental a change in our

\footnotetext{
7 Friedman (1964, p. 1156).

8 See Friedman (1984a, p. 27).

9 See Friedman (1968a, p. 147).

${ }^{10}$ See Friedman and Modigliani (1977, p. 16). This calculation roughly agrees with what emerges from examining present-day data on the modern definition of M2. Using this series, the lowest value of the 14-quarter standard deviation of money growth takes place for the period 1962:Q4-1966:Q1. See Figure 1.
}

monetary system. We must continue to work within the framework of the independent Federal Reserve System" (CSM, 09/28/64). ${ }^{11}$

Friedman's 1965 memorandum applauded the increased average money growth in 1962-65 as an improvement over the inadequate rates of 1958-60, but judged that M2 growth had now overshot its desirable rate. He acknowledged that the upward trend of money growth had so far led to greater output growth with very little increase in inflation, but attributed this to the impact on expectations of the late 1950s period of austerity. Inflationary expectations, he felt, were now returning, and so the time was now overdue for a "moderate reduction" in M2 growth. ${ }^{12}$ When, therefore, the Fed tightened monetary policy in late 1965, raising the discount rate on December 6 , Friedman voiced his approval for the measure (SLGD, 12/09/65).

At the same time, Friedman spoke out against the Johnson Administration's increasing emphasis on wage-price guidelines to restrain inflation. "Price control by exhortation and threat and use of extra-legal powers never has worked and never will, except to disrupt the economy. The cure is worse than the disease. Holding down a few prices here and there only diverts inflationary pressure elsewhere, just as squeezing the corner of a balloon pushes the air into the rest of it" (SLGD, 12/09/65). ${ }^{13}$ He was equally scornful of more general controls: "Direct control of prices and wages does not eliminate inflationary pressure. It simply shifts the pressure elsewhere and suppresses some of its manifestations. The only way to stop inflation is to restrain the rate of growth of the quantity of money" (CT, 05/08/66).

By late 1966, Friedman was worried that the Federal Reserve had moved too far in the direc-

\footnotetext{
${ }^{11}$ In fact, Friedman and Goldwater, while sharing similar limitedgovernment aspirations, had little agreement on economic management issues. Friedman supported the Kennedy-Johnson tax cut, while Goldwater voted against it in the Senate. Friedman viewed inflation in 1970-71 as monetary in origin and opposed wage-price controls; Goldwater blamed cost-push factors and supported price controls.

${ }^{12}$ Friedman (1968a, p. 152).

${ }^{13}$ Here and below, where newspaper coverage of Friedman's public appearances are quoted in the text, the quotations correspond to the direct quotations attributed to Friedman in the articles.
} 
tion of restraint and said the U.S. economy was "headed straight for recession in the next two or three months" (CSM, 12/19/66). Similarly, in Newsweek in early 1967 Friedman wrote that it was "almost surely too late to prevent a recession" (NW, 01/09/67). Actual data now show a sharp slowdown in real GDP growth in late 1966 and the first half of 1967, but no decline in output. There is also no recession in 1967 according to the official National Bureau of Economic Research (NBER) chronology. Nevertheless, Friedman and Schwartz (1982, p. 74), in their own business cycle dating, amended the NBER chronology to categorize 1966-67 as an economic contraction. Partial justification for this choice is that their study was concerned with relations between money stock movements and nominal income movements, and 1966-67 is an important episode in this respect. Nominal income slowed down much more than output, in what Friedman later judged was an unusual instance of inflation responding as rapidly as total spending to a tightening of monetary policy. ${ }^{14}$ In fact, four-quarter CPI inflation actually came back below 3 percent in the first half of 1967 after crossing the 3 percent barrier in 1966. It then rose about 3.5 percentage points over the rest of the 1960s.

In 1968, the joint House-Senate economic committee made a nonbinding recommendation that the Federal Reserve be judged by the criterion of meeting a 2 to 6 percent growth rule for the money supply. Friedman applauded the proposal, suggesting that the most important change would be "for the Fed to be aware of the attitude of Congress" regarding the desirability of steady money growth (CT, 07/05/68). The 1968 proposal in itself came to nothing, but was a precursor to the congressional resolution that established monetary targets in 1975.

\section{WAGE-PRICE CONTROLS AND MONETARY TARGETS: 1969-75}

In January 1969 Friedman called for Federal Reserve Chairman William McChesney Martin Jr.

${ }^{14}$ See Friedman (1972b, p. 14). to step down. Though Martin was due to retire in January 1970, Friedman told Time magazine, "It would be a very good thing if he went early" (TIME, 01/10/69). Despite the public acrimony, Friedman and Martin continued to correspond privately, and in early 1969 Friedman wrote to Martin urging the Fed to adopt a money stock target, with Friedman offering to help design procedures to ensure better control of monetary aggregates. Martin replied that it was "quite true" that better control of monetary aggregates was feasible, but expressed doubt that stabilization of monetary growth was actually desirable. ${ }^{15}$

Friedman welcomed the appointment of Arthur Burns as Federal Reserve Chairman in January 1970, declaring Burns as "the first person ever named Chairman of the Board who has the right qualifications for that post," and expressing the hope that Burns would deliver money growth "high enough to encourage recovery...but low enough to avoid renewed inflation" ( $N W$, 02/02/70). Friedman rapidly became disillusioned when Burns began a series of speeches calling for an incomes policy to help in fighting inflation.

And over the course of 1970, Burns adopted a progressively stricter cost-push analysis of inflation. To Friedman, such an analysis, along with the corresponding policy recommendation of direct government intervention in price and wage formation, was outdated and discredited by empirical evidence. Friedman himself had embraced cost-push views in his pre-monetarist days (see Despres et al., 1950), but it had been superseded in the previous 20 years by his monetarist view of inflation, according to which inflation depended on monetary forces through excessive aggregate spending. As he put it in July 1970, "To each businessman separately it looks as if he has to raise prices because costs have gone up. But then, we must ask, 'Why did his costs go up? Why is it that [for example] from 1960 to 1964 he didn't find that he had to pay so much more for labor he had to raise prices, but that suddenly from 1964 to 1969 he did?' The answer is, because, in the second period, total demand all over was increasing” ( $C D N, 07 / 29 / 70)$.

\footnotetext{
${ }^{15}$ William McChesney Martin Jr. letter to Friedman of April 7, 1969, quoted in Friedman (1982a, p. 106).
} 
The disagreement led Friedman in May 1970 to send Burns a lengthy handwritten letter critical of Burns's statements on incomes policy. The Philadelphia Inquirer reported that Burns was shaken by the letter and suggested that relations between Burns and Friedman had deteriorated (PHI, 05/29/70). A permanent rift between the two occurred. Nevertheless, claims that Friedman and Burns broke off communications completely in 1970 (or 1971) are false. The two met and spoke at the Federal Reserve Board during Friedman's appearances (until 1974) as an academic consultant; and they continued to correspond over 197071. ${ }^{16}$ In 1985 Friedman even described Burns as "still among my closest friends," 17 but this was certainly an exaggeration.

In an interview with the Chicago Daily News, Friedman specifically disputed the notion that strong labor unions had, as claimed by Burns, become important as a source of inflation.

Friedman noted: "You can look around the world and find countries that have had very strong trade unions and no inflation...The fact is that there is little relation between trade unions and inflation" (CDN, 07/29/70). Wage growth, he stressed on a later occasion, was only a symptom of inflation: "It isn't the wet street that caused the rain" $(O K L$, 05/19/81).

Nevertheless, belief in union monopoly power as a cause of inflation remained prevalent.

President Nixon, with Burns's support, introduced wage-price controls on August 15, 1971, beginning with a three-month freeze. Friedman's reaction was that the measures were "purely cosmetic in nature, not therapeutic" ( $N Y P, 08 / 16 / 71)$. Friedman also criticized the controls in a meeting with Nixon in September 1971. ${ }^{18}$

Friedman did react favorably to another of the measures Nixon announced in August 1971: the end of the U.S. commitment to a pegged gold price. A longtime advocate of floating exchange

\footnotetext{
${ }^{16}$ See Friedman (1982a, pp. 106-10).

${ }^{17}$ Friedman (1986, p. 81).

${ }^{18}$ See Friedman and Friedman (1998, p. 387). On a visit to the National Archives in May 2002, Friedman listened to the recording of his September 1971 meeting with Nixon, but found that substantial portions of the recording were unintelligible.
}

rates, Friedman welcomed the end of this mainstay of the postwar fixed exchange rate system. He proclaimed in September 1971, "The Bretton Woods system is dead" (JT, 09/24/71). This judgment was borne out by the failure, over the following 18 months, of attempts to restore international cooperation on fixed-rate arrangements.

At the end of 1971, Friedman renewed his attack both on Burns's diagnosis of cost-push inflation and Nixon's attempted cure of controls. "We have been driven into a widespread system of arbitrary and tyrannical control over our economic life, not because 'economic laws are not working the way they used to,"” Friedman began, alluding to a phrase Burns had used, "not because the classical medicine cannot, if properly applied, halt inflation, but because the public at large has been led to expect standards of performance that as economists we do not know how to achieve."19 Friedman said that Burns's embrace of cost-push views reflected "the propensity of economists to appeal to a change in our economic structure whenever they are puzzled" and that Burns had revived old fallacies about inflation. ${ }^{20}$

In 1973 Friedman went on to declare that controls were the "worst mistake in American economic policy that has been made by an American president in the last 40 years" $(O A K$, 06/15/73) and added that U.S. business leaders had shown "ignorance and shortsightedness" in endorsing the control measures (JT, 10/15/73). Friedman's consistent opposition to guidelines and controls contrasted with the position of leading Keynesian economists during the 1960s and 1970s. For example, Arthur Okun, who had helped shape the Kennedy and Johnson administrations' wage/price guideposts, applauded President Nixon's adoption of wage/price controls. In December 1972 Okun said that some form of wage-price controls would be in effect "for the rest of our lives," adding, "I'll bet a nickel that we never hear another U.S. President say what President Nixon said in 1969 and 1970, that the government has no role over private wage and price decisions" (KCS, 12/07/72). This example

\footnotetext{
${ }^{19}$ Friedman (1972b, p. 17).

${ }^{20}$ Friedman (1972b, p. 11).
} 
and many similar ones show that Krugman (2007b) is incorrect to suggest that Friedman's opposition to the Nixon wage/price controls was widely shared by nonmonetarists.

Though opposed to the changes in inflation analysis that were taking place over 1970-71, Friedman did modify his own position on inflation in one major respect during this period. Before 1971, he had believed that output and inflation reacted simultaneously to prior monetary policy actions. $^{21}$ This led him to predict in August 1969 that inflation would begin declining by the fourth quarter of 1969 (DOM, 08/24/69) and to admit in June 1970 that the impact of the 1969 monetary policy tightening on inflation was "coming later than many of us hoped or expected" ( $C T$, 06/29/70). In late 1971 Friedman reexamined postwar evidence and found an 11- to 31-month lag from monetary growth to inflation, ${ }^{22}$ leading to his later summary of the evidence that there was a two-year lag from money growth to inflation and "output responds more quickly than prices..." 23 The two-year rule of thumb from monetary policy actions to inflation, which entered Friedman's framework in 1971, has since become standard. ${ }^{24}$

If Friedman's confidence about timing relations between money growth and the components of nominal income growth increased in the 1970s, he remained as skeptical as ever about estimating structural aggregate supply relationships. His proposition that the appropriate Phillips curve specification was an expectational version (Friedman, 1968b) was gaining acceptance in academia, but Friedman continued to doubt that a durable specification could be implemented

\footnotetext{
${ }^{21}$ Friedman had always believed that U.S. prices had considerable stickiness; for example, in 1969 he had written, "Inflation has an inertia of its own. Many prices and wages are determined long in advance..." ( $N W, 08 / 18 / 69)$. But he believed that sizable (though incomplete) responses of inflation to monetary policy actions appeared at the same time as output responses and, in late 1970, had modified this only to the view that prices reacted 6 to 9 months behind output (Friedman, 1970b, p. 15).

${ }^{22}$ See Friedman (1972b, pp. 14-15).

${ }^{23}$ Friedman (1975, p. 178).

${ }^{24}$ For example, Bernanke, Laubach, Mishkin, and Posen (1999, pp. 319-20) state that "research regarding how long it takes monetary policy to influence inflation...indicates that the lag is on the order of two years (a common estimate)."
}

empirically. This was especially so with those Phillips curves that used unemployment-based measures of economic slack; Friedman thought that Okun's law relationships were unstable. His doubt, expressed in 1968, that the natural rate of unemployment could be measured reliably was reinforced by evidence that in the 1970s the relationship between the rates of employment and unemployment had loosened (NW, 02/07/77). Asked in 1974 how much unemployment was needed to cure inflation, Friedman gave the nonanswer, "To answer that question is like answering the question, 'When did you stop beating your wife?'” (IT, 09/18/74). Nevertheless, he confirmed that "There is no way of slowing down inflation that will not involve a transitory increase in unemployment, and a transitory reduction in the rate of growth of output. But these costs are far less than the costs that will be incurred by permitting the disease of inflation to rage unchecked" ( $T G$, 09/16/74).

In explaining why monetary conditions had been allowed to become so relaxed in 1972, Friedman judged that "the Fed became worried about rising interest rates" ( $L A T, 02 / 18 / 73)$, adding more generally in 1978 that pressures "to keep interest rates low are a major reason for high monetary growth" (NW, 04/24/78). Friedman emphasized that the failure to allow nominal interest rates to exceed inflation was inhibiting price stability and that only a period of disinflation could permanently deliver low nominal interest rates. Hence his recommendation: "The best way to hold rates down in the long run is for the Fed to raise them temporarily" (LAT, 02/18/73).

In addition to criticizing official efforts to hold down nominal interest rates in securities markets, Friedman condemned the U.S. government for providing inadequate returns to holders of nonmarketable debt. Savings bonds, he declared in early 1976, were the "greatest ripoff in modern history" and "anyone who has bought savings bonds in the past ten years has been taken to the cleaners" (OAK, 02/12/76). He was no less acerbic when he returned to the theme in 1987: "Savings bonds were the biggest steal of all. The government was able to get suckers to buy savings bonds yielding much less than the inflation rate" (SFC, 
08/18/87). In 1974, Friedman had called for government-indexed savings bonds to provide a vehicle for small savers to protect the purchasing power of their assets $(D C, 08 / 16 / 74)$.

With Friedman's criticisms of U.S. monetary policy gaining ground, Chairman Arthur Burns wrote a letter to Senator William Proxmire in November 1973 (subsequently published in Federal Reserve outlets: Burns, 1973) that apparently denied Federal Reserve responsibility for inflation and, in part, for money growth as well. This prompted Friedman himself to write a bristling rebuttal, also in the form of a letter to Proxmire, in early 1974 (Friedman, 1974). Friedman was particularly scornful of Burns's statement, "The severe rate of inflation that we have experienced in 1973 cannot responsibly be attributed to monetary management." "As written," Friedman began (1974, p. 20), "this sentence is unexceptionable. Delete the word 'severe,' and the sentence is indefensible.” Commodity price increases and other one-time events, Friedman said, might explain why U.S. inflation in 1973 reached 8 percent instead of 6 percent, but not why inflation could reach 6 percent in the first place; moreover, the more years one considered, the less valid it was to invoke nonmonetary events to explain inflation. Thus "the Fed's long-run policies have played a major role in producing our present inflation."25

The Federal Reserve did tighten monetary policy over 1973, and in October 1973 Friedman predicted a recession of which already "we might be in the early stages" ( $P H B, 10 / 12 / 73)$. The National Bureau of Economic Research later dated the 1973-75 recession as having begun in November 1973.

October 1973 also saw the OPEC oil embargo and the announcement of permanent oil price increases. Friedman would have a checkered record in predicting the course of oil prices. In September 1973 he had said that food and commodity prices had undergone a "tremendous bubble...[which] cannot last” (NW, 09/17/73), thereby implying that their likely direction was down, not up. When OPEC then announced its

\footnotetext{
${ }^{25}$ Friedman (1974, p. 21).
}

large price increases, Friedman predicted that in four to five years "oil will be coming out of our ears" because "cartels inevitably break up sooner or later" $(P H B, 11 / 09 / 73)$. He later cited the Iran revolution and counterproductive energy policies in the United States as the source of resilience in the oil price for the rest of the 1970s. Weaker oil prices in the early 1980 s eventually provided some support for Friedman's initial skepticism about OPEC, and he accurately predicted further weakness to come. "Betting on continued high oil prices is equivalent to betting on a disruption in the Middle East," he said in Norway in September 1982. "I am not talking about a reduction from $\$ 32$ to $\$ 30$ a barrel, but a drop to somewhere around $\$ 15$ to $\$ 20$ " (SCMP, 09/17/82). His further conjecture that, longer-term, the real oil price would return to its pre-1973-shock value was borne out during some of the 1990s.

Friedman consistently stressed, however, that success in controlling inflation was not contingent on oil prices beyond the very short run. "If you spend more on oil, doesn't that leave you less to spend on something else? Why don't other prices come down, or not rise as rapidly? It's a complete fallacy to suppose that the rise in the price of oil, or of other commodities, has had any significant effect on inflation" ( $T G, 09 / 16 / 74)$.

Wage and price controls came to an end in 1974, but Friedman remained irritated by the proliferation of false cures for inflation. After attending a two-day summit on inflation hosted by President Ford, Friedman deplored the "bewildering variety of proposals for governmental action" (NW, 10/14/74). "You can’t stop inflation without unemployment and stagnation," he added in 1975. "All this business about consumers saving more and reusing paper plates to control inflation-that's nonsense" (PHB, 03/02/75). Friedman also criticized Chairman Burns for still failing to acknowledge sufficiently the Fed's role, in the early 1970s, in producing the inflation surge of 1973-74 (WSJ, 08/21/75). On a more positive note, Friedman was pleased that floating exchange rates had become the norm and judged that they had been "effective shock absorbers" against recent years' events, such as the OPEC shock (WSJ, 06/30/75). 
Another development that Friedman initially saw as very positive was the Federal Reserve's adoption, after a congressional resolution, of monetary targets in 1975. But within a few years he would conclude that the targets had been implemented in a way that had not led to the desired changes in monetary policy. Among Friedman's criticisms of the implementation were that the Federal Reserve avoided accountability by introducing target bands for both M1 and M2 growth instead of a point target for a single aggregate (Friedman, 1984a, p. 27). The Federal

Reserve also continued to use a federal funds rate instead of the monetary base instrument, which Friedman preferred. While Friedman acknowledged that monetary targeting with a funds instrument was feasible, he contended that inertia in adjusting the interest rate meant that monetary target misses would be serially correlated when a funds instrument was used (NW, 12/08/75).

\section{NEW PRESIDENTS, NEW CHAIRMEN, NEW OPERATING PROCEDURES: 1976-80}

With money growth having come down from its peaks in 1972, Friedman in early 1976 predicted accurately that U.S. inflation would fall to 4 to 5 percent by the end of 1976 (JOH, 04/05/76). When this decline came about, however, Friedman voiced unhappiness that achieving 5 percent inflation was now thought of "as doing a good job" (PHB, 11/18/76).

Friedman warned in April 1976 that, while money growth had recently picked up, slow money growth observed in 1975 could interrupt the U.S. economic recovery $(\mathrm{JOH}, 04 / 05 / 76)$. Indeed, Friedman's later verdict on 1976 was that "the [monetary] slowdown in late 1975 produced the economic pause in the second half of 1976 that played such a prominent role in the FordCarter election battle" (NW, 10/03/77). Ford's former press secretary later said that a rise in unemployment before the election, associated with the economic pause, was a decisive factor in President Ford's defeat (USAT, 12/27/06). ${ }^{26}$
Election day 1976 coincided with Friedman's announcement of a change of location. He would leave Chicago at the end of November and move to San Francisco to become a research fellow at the Hoover Institution, Stanford University, following a six-month spell in late 1976 and early 1977 as a visiting scholar at the Federal Reserve Bank of San Francisco (CT, 11/02/76; NYT, 11/03/76).

Shortly after the election, Friedman said he hoped that once in office President Carter would "rise above his advisors" and not try to stimulate aggregate demand aggressively ( $P H B, 11 / 15 / 76)$. He also provided a scenario, in a December 1976 Newsweek column, regarding the likely result of following expansionary policies in 1977, which proved to be prophetic:

If Mr. Carter tries to put his advisors' policies into effect and succeeds in doing so-including getting the Federal Reserve System to speed up substantially the rate of monetary growththere might be a sudden spurt in the economy and a quick reduction in unemployment. However, these good results would be temporary. By 1978 or 1979, inflation would be back in double digits and wage and price controls would be in place or in contemplation. By 1980 at the latest, unemployment would be rising sharply. As Machiavelli might say: what a way to face the 1980 election! (NW, 12/06/76)

It was probably this commentary that President-elect Carter had in mind when in December 1976 he asked to be put through to Milton Friedman and began, "I've wanted to talk to you, but first let me congratulate you on the [Nobel] prize." Unfortunately, Carter's staff had connected him not to Milton Friedman but to Mr. Milton (Milt) Friedman, a member of President Ford's staff (DFP, 12/25/76) ${ }^{27}$ Carter's staff finally connected him to the Milton Friedman, who later described his conversation with Carter as a "pleasant talk" but provided no details (Friedman and Friedman, 1998, p. 459).

\footnotetext{
${ }^{26}$ The unemployment rate in the third quarter of 1976 was slightly higher than in the previous quarter.

${ }^{27}$ Ford's staff member Milton Friedman had served as senior speechwriter and special assistant to the President (TDN, 02/05/76).
} 
The pleasantries did not endure into 1977 and, shortly after Carter took office, Friedman spoke dismissively of the new administration's proposed tax rebate. Reaffirming his skepticism about the effectiveness of fiscal policy, Friedman asked an interviewer, "How can the government stimulate the economy by taking money out of one pocket of the public and putting it into another pocket?" (USNR, 03/07/77). Carter withdrew the tax rebate proposal in April 1977.

In an interview with a St. Louis reporter in late 1977, Friedman returned to the themes covered in his Nobel lecture of a year earlier. ${ }^{28}$ "[I]nflation is a lot like alcoholism," he said. "When you drink, the good effects come first, and the hangover comes the next morning. When an inflationary period starts, spending goes up and employment rises along with it." By an "inflationary period," Friedman explained he meant the initiation of an easy monetary policy, which usually preceded the actual upturn in inflation. "By printing money at a faster rate you may be able temporarily to create an appearance of prosperity, but only so long as you fool the people. Once the public comes to realize what is going on, higher inflation means higher unemployment! Just look at the example of the U.S., Great Britain, and every other country" (SLGD, 12/16/77).

Friedman was asked whether he thought Chairman Burns would receive another term from President Carter. Friedman said it would not make much difference: Despite an inflationfighting reputation, Burns in practice had produced "a Fed which is promoting inflation." Monetary targets had not made a difference to this, said Friedman, because "while the targets are going down, actual monetary growth is going up" (SLGD, 12/07/77). His own opinion was that the "chances are good" that Burns would be reappointed (SLGD, 12/16/77). In late December 1977, Carter actually announced a new Chairman, G. William Miller, who took office in March 1978 and about whom Friedman ultimately wrote very little.

In April 1978, double-digit M2 growth in 1977 led Friedman to predict that "inflation from

\footnotetext{
${ }^{28}$ The 1976 Nobel lecture was published as Friedman (1977).
}

February 1977 to October 1979 will average something like 7 to 10 per cent...[and] no sustained reduction in inflation can be expected before midor late 1979" ( $N W, 04 / 24 / 78)$. The following month Friedman made more specific predictions: Inflation "probably will be eight or nine per cent by the end of the year, and may be in double digits in 1979" (MHER, 05/22/78). These predictions were realized.

The appointment of Paul Volcker as Federal Reserve Chairman in 1979 gave Friedman an opportunity to reflect on the record of money growth and inflation in the past two decades. He noted that inflation exhibited a steeper upward trend since 1960 than did M2 growth. This was "no mystery...It reflects the widening recognition that inflation is the way of the future. Those inflationary expectations make it prudent for all of us to reduce the fraction of our assets in the form of money." This pattern, in reverse, would become important in interpreting 1980s monetary developments. Friedman continued, "The problem is not, as President Carter asserts, a lack of confidence. The problem is rather that the public is very confident that the government will produce inflation and will mismanage the economy. We do not need more confidence in bad policies. We need better policies" ( $N W, 08 / 20 / 79)$.

In October 1979, the Federal Reserve inaugurated its new operating procedures, intended to deliver greater control of monetary growth and permit larger transitory fluctuations in the federal funds rate. Speaking to a local reporter shortly after the procedures were announced, Friedman called them a "long overdue change," but added, "I remain skeptical until I see proof" that a material change in policy had taken place. The need for a change in regime was urgent, Friedman said, because "sooner or later, the adverse effect of inflation will destroy the country" (SFC, 10/18/79).

In July 1980, Friedman pronounced a negative verdict, declaring that the erratic money growth of the preceding months was a "disgraceful performance" that "confirms the doubts rather than the hopes" about the new regime (NW, 07/14/80). In May 1981 he further declared, "After studying the Fed for [its] 67 years, I have no doubt that the United States would be better off if the Federal 
Reserve had never been established" (NYDN, 05/22/81). In these and other critiques, Friedman cited the Fed's failure to reform its arrangements with commercial banks as a major reason for the instability in money growth. In particular, throughout 1979-82 (and into 1984), the required amount of reserves that commercial banks had to keep with the Federal Reserve continued to be determined on the basis of prior deposit levels. This made aggregate reserves predetermined in the short run and so inhibited short-run control of the money stock.

Besides the new operating procedures, Friedman was highly critical of direct controls on credit introduced by President Carter and the Federal Reserve in March 1980. Friedman (1982a, p. 103) said the rationale for the controls was the fallacious real-bills doctrine, according to which certain types of spending are particularly inflationary, so that control of inflation requires discouraging these spending categories. This contrasted with Friedman's own view that inflation responded to total spending. Friedman also argued that the controls would have adverse effects on saving and investment ( $N W, 04 / 14 / 80)$. While ostensibly the controls applied to credit rather than money, the controls had a noticeable downward effect on money growth, and output collapsed in the quarter following the controls' imposition. The credit controls were withdrawn in July 1980.

On November 4, 1980, Ronald Reagan, about whom Friedman had written supportively both during 1980 and in Reagan's 1976 campaign for the Republican presidential nomination, was elected president. Three days after the election, the Soviet Union's state-controlled press commented on the result, in the form of an article in Pravda. The commentary noted, "In Ronald Reagan's entourage are found such experienced public figures as former Treasury Secretary William Simon, economists Alan Greenspan and Milton Friedman, and other well-known people." 29 Ulam (1983) suggests that this respectful reference to Friedman exemplified the Soviet authorities' regard for opponents who exhibited ideological consistency. If this assessment is accu-

${ }^{29}$ Quoted in Ulam (1983, p. 288). rate, the respect for consistency presumably offset the Soviets' opposition to much of Friedman's record, including his advocacy of free markets and his recent meeting with Chinese government officials. On the other hand, Friedman's views on monetary policy were probably not among his most objectionable opinions for Soviet officials; after all, as Friedman wryly observed on several occasions, Karl Marx was a monetarist. ${ }^{30}$

\section{THE YEARS OF CONFUSION: 1981-85}

The years 1981 to 1985 saw several major blemishes appear on Friedman's forecasting record, and many changes in the details of his analysis of recent U.S. monetary policy developments. The outcome was a confused record of public statements on Friedman's part. By far, the period 1981-85 marks Friedman's most inconsistent period since he became a monetarist in 1950-51. ${ }^{31}$ It was 1986 before Friedman settled on positions in describing 1980s developments that he maintained for the remaining 20 years of his life.

In September 1981, Friedman commented in Newsweek that "Institutional change, notably the explosion in money-market mutual funds, has rendered narrow monetary aggregates misleading." He accordingly used M2 to judge monetary policy settings ( $N W, 09 / 21 / 81$ ). If Friedman had stuck with this judgment throughout the following years, he would probably have been able to avoid some of his worst-and most-publicized-macroeconomic forecasts. Certainly in 1981-82 Friedman's record on inflation forecasting continued to be good; in October 1981 President Reagan told the press that inflation was "in single digits now, and I was interested to see that our Nobel economics prize winner, Milton Friedman, has just been quoted as saying that he believes it'll be down

\footnotetext{
${ }^{30}$ See for example Friedman's article "Marx and Money" (NW, 10/27/80).

${ }^{31}$ David Laidler, an admirer and former student of Friedman, nevertheless certainly had Friedman in mind when he referred (Laidler, 1990, p. 59) to "careless monetarist predictions" that were made in the early stages of the economic recovery that began in 1982 .
} 
to six percent next year" ( $W C P D, 10 / 16 / 81)$. This forecast, presumably based on the lower M2 growth after 1977, was borne out in U.S. inflation outcomes in 1982. ${ }^{32}$

But in early 1982, Friedman abruptly switched to using M1 on a near-exclusive basis (e.g., $N W$, 02/15/82). In October 1982, the Federal Reserve, which had already shown signs since late summer of switching to a federal funds rate target, announced that it was "de-emphasizing” its M1 target on account of continuing financial innovations. Friedman's reaction to the double-digit M1 growth that followed in 1982-83 was to predict a revival of inflation.

Indeed, from 1982 to 1985, Friedman repeatedly predicted a major revival of inflation that never occurred. In 1982 he predicted 8 percent inflation for 1983; the outcome was around 4 percent (FORT, 03/19/84). In July 1983, Friedman wrote, "We shall be fortunate indeed if we escape either a return to double-digit inflation or renewed recession in 1984" (NW, 07/25/83). In August 1983, he said, "U.S. inflation rates will rise appreciably in 1984, although it's not yet determined where they'll go from there" (TSN, 08/30/83). In April 1984, Friedman said, "I believe [the CPI] will be rising in the neighborhood of 8 to 10 percent in 1985." 33 Even in November 1985, Friedman said that "Inflation is not dead. It will emerge once again and will be higher next year than it is this year. We almost surely are currently at the bottom of this inflationary episode and are likely to be starting up again" (NYDN, 11/13/85). Defying these predictions, inflation was consistently below 5 percent in every month from 1983 to 1986; moreover, apart from a brief uptick in early 1984, inflation continued to decline after 1982, and was lower in 1986 than it was in 1985.

Questions that arise are why Friedman increased his reliance on M1 in 1982 even as the Fed was deemphasizing it; and why he in 1982-85 attached little weight to the position that financial innovations were distorting M1, even though he had taken this position himself in 1981.

\footnotetext{
${ }^{32}$ In February 1982, Friedman went on to forecast 5 to 6 percent CPI inflation by the end of the year (STR, 02/19/82).

${ }^{33}$ Friedman in Heller et al. (1984, p. 46); see also NYT, 04/30/84.
}

To answer these questions, it is worth going back to Friedman's past preferences in defining money. As Friedman recalled in 1984, "In the past, I always found M2 to be a more reliable guide to economic events than the earlier M1." 34 His and Schwartz's Monetary History had used M2 as their money series, and they had defended this choice at length in their 1970 Monetary Statistics. ${ }^{35}$ This position hardened in 1978 when Friedman saw the prospect of sweeps programs making M1 "a nearly useless aggregate" ( $N W, 10 / 30 / 78)$, though in practice sweeps did not become a pervasive distortion until the 1980s and 1990s.

In 1980, the Federal Reserve made M1 and M2 much broader definitions than they had previously been. The new definitions of money were based on the type of deposit, irrespective of whether the deposit was a liability of commercial banks or of nonbank financial institutions. (So, for example, demand deposits of nonbanks, previously included in neither M1 nor M2, were now included in both M1 and M2. ${ }^{36}$ ) Friedman was initially inclined to rely on the new M2 and, as we have seen, argued in 1981 that M2 was more immune to distortions from financial innovation.

But again, why did he come to rely on M1? One major reason was the close relationship that M1 growth and nominal income growth enjoyed in the early 1980s-a "hot streak" of M1, discussed here later. In addition, M1 gave a more unambiguous picture of tight money over 1981 and into 1982 than did M2, and so gave an accurate signal both of the severe 1981-82 recession and the 1982-83 decline in inflation.

Friedman's discounting of the Fed's rationale for its deemphasis on M1 arose partly from experience; it was not the first time the claim had been made that financial innovations were disturbing velocity behavior. In January 1977, Friedman had said, "I have observed over a long period of time that whenever anything goes wrong with monetary policy, the favorite excuse of the monetary authorities is that there has been an exogenous

\footnotetext{
${ }^{34}$ From his remarks in Heller et al. (1984, p. 51).

35 See Friedman and Schwartz $(1963,1970)$.

${ }^{36}$ See Anderson and Kavajecz (1994).
} 
shift in the demand for money." 37 Similarly, Friedman wrote in August 1982 that "the talk about changes in the demand for money is simply a red herring introduced by the Federal Reserve... In each case it has turned out that there has been no change in the demand for money..."38 Friedman was also chastened by his own lapse in 1972, when he had briefly persuaded himself that the high money growth of 1971-72 had been permanently absorbed by a velocity shift and so did not signal future inflation ( $N W, 10 / 16 / 72)$.

An article Friedman presented at the December 1983 American Economic Association meetings, and which was published in 1984, represented the high point of his confidence in M1 and so combined a number of judgments that he would retract within a few years. He stated (Friedman, 1984b, p. 398) that "Few if any monetarists ever recommended the use of such broad aggregates as the current M2 or M3 as monetary targetscertainly, this one did not." (This was not accurate- he had advocated M2 targeting in Friedman [1982a, p. 117] and would again from 1986 on.) He also stated that "The current M1 is conceptually...closer to the aggregate we [Friedman and Schwartz] labeled M2 rather than to our M1..." (This claim was also inaccurate: Federal Reserve data showed that old M2 and new M2 were more correlated than old M2 and new M1 before 1979. ${ }^{39}$

\footnotetext{
${ }^{37}$ Milton Friedman, January 26, 1977, quoted in Friedman and Modigliani (1977, p. 26).

${ }^{38}$ Friedman (1982b). Other critics of the Federal Reserve took the same perspective but expressed it with more intemperate language For example, Maxwell Newton, a monetarist financial columnist, wrote in October 1982: "The justification offered to an evidently credulous world for the Fed's decision to allow the money stock M1 to float way above target in the coming weeks is the hoary old lie brought out by the Fed from time to time-namely that 'financial innovations' have made M1 less relevant or less accurate as a measure of 'money.' This lie has been proffered by the Fed for at least 40 years" (NYP, 10/12/82). By 1987, Newton had accepted that M1 actually was distorted by financial innovations and had switched to focusing on M2 in his analysis (TT, 07/20/87).

${ }^{39}$ Correlations computed from the data for 1973:Q1-1979:Q4 tabulated in the Federal Reserve Bulletin (Simpson, 1980, p. 112) indicate that old M2 quarterly growth had a correlation coefficient of 0.54 with the new M1 growth series and 0.67 with the new M2 growth series. At various points, Friedman (e.g., 1984b, p. 398) claimed that the new M1 was similar to the old M2 because the new M1 series included interest-bearing deposits. But this claim did not really hold up. The velocity of M1 remained much more sensitive to variations in market interest rates than did M2, reflecting the fact that interest-bearing, variable-rate accounts were much more important for M2 than for M1.
}

Also, the new M1 shared with the old M1 the "stylized fact" of an upward velocity trend in the 1960s and 1970s, while the new M2 shared with the old M2 a basically trendless velocity over those decades.)

In retrospect, Friedman underestimated the impact of financial innovations on M1, as well as the extent to which high M1 growth reflected a recovery of real balances after a disinflation. He did acknowledge the latter as a factor in reducing the level of velocity in 1982-83 (WSJ, 09/01/83), but underestimated the extent of the increase in money demand. Part of his error here reflected his viewing M1, which is highly interest-elastic, as similar to old M2, whose demand function was less interest-inelastic. Consequently, he underestimated the impact that the shift to lower nominal interest rates from 1982 had in reviving the demand for real balances. In addition, while aware that much of the 3 percent per year pre-1981 trend growth rate of M1 velocity was due to the inflationary monetary regime, Friedman initially conjectured that even under price stability velocity would grow at about 1.5 percent per year because "technological improvements in cash management" were not yet exhausted. ${ }^{40}$ It soon became clear that disinflation since 1981 had instead eliminated the M1 velocity trend altogether.

In May 1986, Friedman undertook a fundamental review of the monetary data in light of developments in recent years, including his own poor forecasting record on inflation, and settled on M2 (with a one-time adjustment for the introduction of money market deposit accounts in the four months to March 1983) as the appropriate money series for U.S. monetary analysis. ${ }^{41}$ This became the position he stuck to. If, as Friedman thus concluded, monetary policy developments in the early 1980s should have been analyzed using M2 rather than M1, how does the picture of this period change? The basic assessment that monetary policy variability increased in the early 1980s is supported by using series other than M1. Friedman's (1984a, p. 29) tabulation of money growth showed that the ups and downs of M1

\footnotetext{
${ }^{40}$ Friedman (1984a, p. 58).

${ }^{41}$ See Friedman (1988, pp. 229, 239-40).
} 
and M2 growth over 1979-83 were basically similar, while Erceg and Levin (2003) estimate that the monetary policy swings in the early 1980s produced considerable variability in private sector estimates of the long-run inflation rate. Also consistent with these authors' findings is Friedman's statement that a principal channel through which money growth variability was manifesting itself in economic variability was interest-rate variability: As he put it, "What accounts for this unprecedentedly erratic behavior of the U.S. economy? The answer that leaps to mind is the correspondingly erratic behavior of interest rates" ( $N W$, 02/15/82). Friedman also judged that the high variability had itself contributed to the downward pressure on aggregate demand, making the recession worse and producing a larger decline in inflation than would be expected from the decline in money growth alone (ESN, 10/21/82; Friedman, 1984b).

There are, however, some differences in an account of 1979-82 that uses M2 rather than M1. M1 growth unambiguously fell in the period from late 1979 to mid-1982. M2 on the other hand, as Friedman noted in 1981, was "flat" over 1978-81 in its annual average growth rates ( $N W, 09 / 21 / 81)$, at about 8.5 percent, and continued at around this rate in 1982. Seen from the perspective of M2 growth, the 1979-82 period amounted to a monetary policy sufficiently tight to hold the line on the reduction in M2 growth achieved in 197778 , frustrating the strong upward pressure on the nominal quantity of money demanded that was coming from high rates of nominal spending growth.

In addition, while M2 velocity was roughly trendless since the mid-1950s, it nevertheless exhibited sustained movements over shorter periods, rising in the 1970s and falling about 7 percent over 1981 and 1982. In line with his 1979 discussion of why inflation had risen more steeply than M2 growth, Friedman attributed the high money growth relative to inflation to agents' flight back into money once they were confident inflation had peaked (WSJ, 02/12/87). Studies by Friedman and others found that M2 velocity behavior in the postwar period could be accounted for by opportunity-cost variables, leading
Friedman to conclude that velocity in the 1980s was explicable "despite all the talk about how the relation between money and other variables has shifted drastically in recent years." 42 M2 velocity settled down after 1983, by which time most of the larger opportunity-cost movements had taken place. ${ }^{43}$ Therefore, Friedman was able to observe in June 1988 that from 1983:Q1 to 1988:Q1, nominal GNP had grown 7.4 percent per year and M2 7.5 percent: "How much closer can you get for a five-year period?" (WSJ, 06/22/88).

Friedman's reliance on M1 in the mid-1980s led him not only to successive errors in forecasting inflation, but also a well-publicized erroneous short-term forecast for 1984. The sharp decline in M1 growth during the second half of 1983 led him to predict a recession starting in 1984:Q1. "Mr. Reagan may well face a very difficult situation by next fall," Friedman said in late 1983. "There is a real threat of a recession in the first half of 1984" (NYT, 12/31/83). Instead, real growth continued throughout 1984 and was exceptionally strong in 1984:Q1. "I have no easy explanation of what went wrong," Friedman said after the strong output numbers were released (NYT, 04/30/84).

Friedman was, however, not as misguided in his recession forecast as he had been in his inflation predictions. While he was proven wrong in his forecast of a recession in 1984:Q1, Friedman was on the right track when he continued to maintain that "there is not enough monetary fuel going into the economic engine" and that this had to show up before long in slower real and nominal income growth (NYT, 04/30/84). The Fed had, indeed, withdrawn a lot of monetary stimulus in the second half of 1983 and continued to do so in 1984 . The move to restriction was evident not only in the questionable M1 data but in monetary base growth and rising real interest rates. What happened, in line with Friedman's expectation, was a substantial slowdown in real and nominal income growth during 1984-but, contrary to his expectation, it commenced in 1984:Q2 and was not associated with a recession.

\footnotetext{
${ }^{42}$ Friedman (1988, p. 229).

${ }^{43}$ See Small and Porter (1989, pp. 245-46).
} 
Rather, the United States had a "soft landing," instead of an overreaction to the unsustainably high real growth of 1984:Q1. In fact, the early-tomid 1984 period is now regarded as the pivotal period in which the United States transitioned to the "Great Moderation" and so a much more stable business cycle (see, e.g., Bernanke, 2004; Blanchard and Simon, 2001; McConnell and Perez-Quiros, 2000; and Stock and Watson, 2002). Based on the prior experience that Friedman had studied, big withdrawals of monetary stimulus implied a recession; but the 1984 episode produced an example of a better transition of the economy from over-rapid growth. ${ }^{44}$

On top of his very public errors in forecasting inflation and recession, 1984 proved a dismal year for Friedman on several other fronts. His and Rose Friedman's television program The Tyranny of the Status Quo (a follow-up to their 1980 success, Free to Choose) flopped, Newsweek dropped him as a columnist, and in October he suffered a heart attack. In December he was able to record success by putting things into a longer perspective, telling the Wall Street Journal, "It's widely accepted that you can't hold inflation down unless you hold down the money supply. Thirty years ago, people didn't agree with that" (WSJ, 12/10/84).

\section{The Battle of the Friedmans}

In light of Milton Friedman's awful forecasts for 1984, finding fault with his monetary analysis during this period should be like shooting fish in a barrel. It happens, however, that two such critiques, by Benjamin Friedman and Alan Blinder, that appeared during the 1980s contain oversights that, when corrected, lead to support for some aspects of Milton Friedman's analysis during the early 1980s.

Benjamin Friedman (1988, p. 61) critically considers Milton Friedman's (1984b) statement that the relation between nominal GNP and M1 growth was "unusually close" and, using 1987vintage data, states that "The GNP-to-lagged-M1 correlation was not 'unusually close' during

\footnotetext{
${ }^{44}$ In addition, some of the slowdown in nominal spending was recorded in a fall in the annual inflation rate of about 1 point over 1984 rather than slower economic growth.
}

1979:Q4-1983:Q4 compared with the past...The correlation of $0.45 \ldots$ is essentially identical to that for the previous 79 quarters."

On closer inspection, this claim of Benjamin Friedman's does not stand up as a refutation of Milton Friedman, as it overlooks key elements of what was said in the 1984 article. What Milton Friedman (1984b, p. 399) said of M1 growth and nominal GNP growth was "From 1981 on, the relation is extraordinarily close-indeed, instead of being less close than during the earlier [pre1979] years, is considerably closer...Two things are notable...first, the lag is both shorter on the average...second, the relation is unusually close" (emphasis added).

In evaluating Milton Friedman's position, Benjamin Friedman overlooked the statement that the claimed close relationship was from "1981 on." Once this aspect of Milton Friedman's statement is taken into account, Benjamin Friedman's challenge to Milton Friedman's contention regarding the $\mathrm{M} 1 /$ nominal income relation under the new operating procedures is refuted. As Table 1 shows, the peak M1/future income correlation is unusually high from 1981 on (whether 1981-83 or 1981-84 is considered), compared with pre-1979 correlations. Moreover, Milton Friedman's statement, ignored by Benjamin Friedman in his calculation of correlations, that the lag was shorter after 1979 is also supported: The peak correlation is with a two-quarter lead for M1 growth up to 1979, but with a one-quarter lead for both 1979-83 and 1981-83. ${ }^{45}$ Thus, when the sample considered is restricted to begin with the period to which Milton Friedman explicitly indicated that his comments pertained, Milton Friedman's contention that the relationship is unusually close is confirmed, while Benjamin Friedman's counterclaim is rejected.

On a similar note, Blinder (1984, p. 267) offered as evidence of a "shift in the moneyincome relationship" a table which "show[ed]

\footnotetext{
45 Benjamin Friedman's comparison of one-quarter correlations before and after 1979 in judging the strength of correlations across periods thus overlooks Milton Friedman's explicit statement that the lag from money growth to income growth was longer before 1979. The practical effect of this is that the correlations reported by Benjamin Friedman understate the strength of the M1/income relationship both before and during the new operating procedures.
} 


\section{Table 1}

\section{Correlations of Nominal Income Growth and Prior M1 Growth}

\begin{tabular}{|c|c|c|c|c|c|c|}
\hline \multirow[b]{2}{*}{ Correlation with M1 growth } & \multicolumn{4}{|c|}{$\begin{array}{c}\text { Using } 2006 \text { vintage of nominal GDP and M1 data } \\
\text { (annualized quarterly growth rates, } \\
\text { seasonally adjusted) }\end{array}$} & \multicolumn{2}{|c|}{$\begin{array}{l}\text { Using Blinder (1984) } \\
\text { data }\end{array}$} \\
\hline & $\begin{array}{c}\text { 1960:Q1- } \\
\text { 1979:Q3 }\end{array}$ & $\begin{array}{c}\text { 1979:Q4- } \\
\text { 1983:Q4 }\end{array}$ & $\begin{array}{c}\text { 1981:Q1- } \\
\text { 1983:Q4 }\end{array}$ & $\begin{array}{c}\text { 1981:Q1- } \\
\text { 1984:Q4 }\end{array}$ & $\begin{array}{c}\text { 1981:Q1- } \\
\text { 1983:Q1 }\end{array}$ & $\begin{array}{c}\text { 1981:Q1- } \\
\text { 1983:Q4 }\end{array}$ \\
\hline In same quarter & 0.480 & 0.098 & -0.196 & -0.152 & -0.425 & -0.275 \\
\hline One quarter earlier & 0.449 & 0.543 & 0.660 & 0.604 & $0.515^{*}$ & $0.669^{*}$ \\
\hline Two quarters earlier & 0.515 & 0.227 & 0.595 & 0.570 & $0.024^{\dagger}$ & $0.551^{+}$ \\
\hline Three quarters earlier & 0.383 & -0.217 & -0.260 & -0.155 & $-0.741^{\ddagger}$ & $0.237^{\ddagger}$ \\
\hline
\end{tabular}

NOTE: *Starting in 1981:Q2; ${ }^{\dagger}$ starting in 1981:Q3; ${ }^{*}$ starting in 1981:Q4. Blinder (1984) data measures nominal income by nominal GNP. SOURCE: For 2006 vintage data: FRED (Federal Reserve Bank of St. Louis).

that during the nine-quarter period 1981 Q1 to 1983 Q1 there was actually a remarkably strong negative correlation between money growth and nominal GNP growth.” But as Table 1 shows, the data given in Blinder (1984) again confirm the strong positive correlation between M1 growth and next-quarter nominal GNP growth claimed by Friedman (1984b), for samples ending in both 1983:Q1 and 1983:Q4. The negative correlation noted by Blinder is evident only in the contemporaneous relationship. The specific evidence offered by Blinder in 1984 is therefore less a demonstration of the absence of a money-income relationship than it is confirmation of Friedman's (1980, p. 59) warning that "failure to allow for lags in reaction is a major source of misunderstanding" and of the 1997 observation of one former policymaker that "lags tend to be trivialized or ignored in academia...Failure to take proper account of lags is, I believe, one of the main sources of central bank error." 46

The breakdown of M1's tight early-1980s relationship with nominal income led Friedman back to M2, but he conjectured that the same break had led critics of monetarism to overemphasize the extent to which money/income relationships had changed in the 1980s. Friedman came to see the closeness of M1 to GNP from 1981 as a "hot

\footnotetext{
${ }^{46}$ Blinder (1997, p. 8).
}

streak" that ended in 1984 and judged that M1 was, in fact, more distorted by financial innovation than other aggregates-i.e., the monetary base and M2 (WSJ, 09/18/86; Friedman 1988, p. 224). More generally, Friedman reaffirmed, "The relationship between the money supply and the state of the economy has always been a loose one" (SFC, 07/04/86).

Friedman also stressed that, while financial deregulation had distorted monetary aggregates such as M1, he supported deregulation. "Deregulation is good. That is the one good thing-the only good thing, in my opinion-that has come out of this [i.e., the inflation/disinflation experience]."47 Indeed, Friedman (1960, 1970c) had called for the deregulation of commercial banks' interest rates that ultimately took place in the 1980s. He did argue that the inflation and interestrate peaks in the 1970s and early 1980s had exacerbated the distortions arising from financial regulation and thus increased the distortion to monetary aggregates when deregulation took place. ${ }^{48} \mathrm{He}$ did not feel that financial regulation was a cornerstone for control of monetary aggregates or of aggregate demand: Open market operations were sufficient for monetary control (Friedman, 1974; FT, 02/23/87), and lack of reg-

\footnotetext{
${ }^{47}$ From his July 1986 comments in Darby et al. (1987, p. 10).

${ }^{48}$ Friedman (1985a, p. 59).
} 
ulation of financial institutions "in no way enables them to escape the discipline of the Fed's monetary actions" (WSJ, 06/30/75).

As shown above, the main critiques of Friedman's 1980s positions have their own weaknesses. Nevertheless, Benjamin Friedman (1988) was on solid ground in his demonstration that Milton Friedman (1984b) forecast higher inflation for 1983-85 from higher M1 growth and that this proved very erroneous. "I've gone back to using M2 and only M2,” Milton Friedman told the present author much later. "I slid away from the true and narrow path in the 1980s, and was sorry for it!... I think those predictions in the '80s were bad, but I think on the whole my Newsweek predictions stand up pretty well." 49

\section{FROM VOLCKER TO GREENSPAN: 1986-92}

Friedman remained a persistent critic of Chairman Volcker, criticizing Volcker's reappointment by President Reagan in July 1983. Speaking in October 1983, Friedman acknowledged that Volcker had "brought inflation down," but maintained that it was still "not a good monetary policy" because it was so erratic. ${ }^{50}$ In early 1987 , Friedman returned to this theme, criticizing Volcker's current "seat of the pants" policy and claiming of 1979-82 that "If somebody had wanted deliberately to discredit monetarism they would have done what Volcker did" (FT, 02/23/87).

Friedman's relations with Volcker's successor, Alan Greenspan, would be vastly better. Though Friedman had rarely mentioned Greenspan in his writings, the two were old friends. When Greenspan was appointed Chairman of the Council of Economic Advisors in 1974, Friedman had praised him as a "very good man" who would resign on principle if there were another 1971-style lurch to expansionary policies (CT, 07/17/74). In turn, Greenspan in late 1986 had praised Friedman as one of the 20th century's major

\footnotetext{
${ }^{49}$ Milton Friedman, interview with the author, Stanford University, January 22, 1992.

${ }^{50}$ Friedman (1985b, p. 41).
}

intellects (SFC, 12/26/86). After Greenspan was nominated as Chairman, Friedman said, "I'm a good friend of Alan Greenspan. He's an able person" (MINN, 06/03/87), though Friedman maintained he would still rather have the Federal Reserve replaced by a computer. "I send my congratulations to Alan. And my sympathy" (SFC, 06/08/87).

In a 1981 appearance at a Brookings Institution meeting, Greenspan had stressed the value of M2 as a monetary indicator, ${ }^{51}$ and M2 did figure quite heavily in monetary policy discussions in Greenspan's first four and a half years as Chairman. Aside from a loosening after the 1987 stock market crash, Greenspan undertook a moderately restrictive policy in his first two years that saw annual M2 growth fall below 5 percent and the federal funds rate briefly reach double digits. Friedman approved, offering his opinion that Greenspan "on the whole has been doing very well” (TST, 03/11/89). As for inflation, Friedman said that it was "likely to decline sharply over the next several years" due to the fall in M2 growth (WSJ, 07/05/89). At the end of the decade Friedman's assessment was very optimistic: “There's no reason why the '90s shouldn't be as good as the '80s, or better. There's no reason we shouldn't have a decade of rapid growth and relatively low inflation" (TIME, 01/01/90).

Friedman's optimism about the 1990s was eventually vindicated in spades. But in the interim, there was a spike in inflation in 1990 and what Friedman in May 1992 called "three years of stagnation" 52 from mid-1989, including the 1990-91 recession. By late 1992, while noting the achievement of low inflation, Friedman felt that U.S. monetary policy had begun to exhibit "perverse fine-tuning" — an inadvertently restrictive policy due to giving too little weight to low money growth and too much weight to low interest rates in judging conditions. Friedman called for a more expansionary monetary policy consistent with bringing M2 growth back inside its announced target range. Doing so, Friedman wrote, would mean that inflation would converge

\footnotetext{
${ }^{51}$ See Brookings Institution (1981, p. 198).

${ }^{52}$ Friedman (1992, p. ix).
} 
on its ideal value-_a level that would make it irrelevant to individual and business decisions" (WSJ, 10/23/92). This form of words describing the ideal inflation rate was similar to those that became prevalent among policymakers later in the 1990s. ${ }^{53}$

\section{ENTERING THE NEW ECONOMY: 1993-2001}

In October 1993 Friedman wrote that "the opportunities are there for the making of a second industrial revolution" (FEER, 10/28/93) ${ }^{54}$ from the previous decades' breakthroughs in information and telecommunications technology. In August 1995, however, he added his voice to those economists expressing puzzlement that U.S. productivity growth did not seem to have increased in the information age (WSJ, 08/01/95). It transpired that the U.S. productivity trend was already undergoing an upward shift as he wrote those words.

The mid-1990s also gave Friedman opportunities for introspection, including an appearance on CSPAN's program Booknotes in 1994. The question of how many books he had written prompted Friedman's reflection, “Oh, I don't know-fifteen...[T]here's no question that the most influential book I've written is not Free to Choose, but a book that sold probably onetwentieth as many, five percent as many copies, namely A Monetary History of the United States, which I wrote jointly with Anna Schwartz...A Theory of the Consumption Function is, in my

\footnotetext{
${ }^{53}$ Friedman had given a related formulation in 1981: "I think the best of all worlds is one where you have no inflation and no indexation. Indexation is not a good thing in and of itself" (NZH, 04/18/81). In his 1992 article Friedman wrote as though the definition of price stability he gave was also that stated by the Federal Reserve, which is consistent with Orphanides's (2006) tracing of this definition to Paul Volcker.

${ }^{54}$ Friedman attributed the post-1973 slowdown in economic growth to greater government intervention in the economy since the $1960 \mathrm{~s}$ $(N W, 08 / 23 / 82)$. While he believed that inflation (and false cures for inflation) had damaged potential output, Friedman did not believe that the restoration of low inflation would in itself restore high growth. He said in 1982 that low growth and high inflation were "two distinct phenomena, and monetarism is concerned only with the inflation problem" (DS, 01/18/82; my translation) and reaffirmed in 1987 that "it's a great mistake to connect too closely the level of inflation and the rate of economic growth" ( $J P, 11 / 11 / 87)$.
}

mind, the best thing I ever did as piece of science, [while] Monetary History is undoubtedly the most influential, and Free to Choose is the best selling, so they are not similarly characterized" (BOOKN, 11/20/94). ${ }^{55}$

Friedman had predicted in early 1991 that inflation would fall to 2 percent in coming years, based on the low M2 growth maintained under Greenspan (FUT, 03/01/91). In January 1998, by which time inflation had stood at about this level for five years, Friedman said in a television interview that "Right now, inflation is relatively low. Alan Greenspan and the Federal Reserve have done a good job of keeping monetary growth low and fairly steady" (CNN, 01/23/98).

Shortly afterwards, Friedman gave a more detailed evaluation of the Greenspan regime in an interview for Barrons (BAR, 08/24/98). He again praised the outcome of "the lowest and least variable rate of monetary growth" compared with comparable periods. But he also acknowledged some weaknesses of M2 as an indicator during the 1990s: "I think there is no doubt that in the Nineties, from '92 to '95, around there, there was a very sharp uptick in the velocity of M2 and that targeting money supply at that time in a rigid fashion would not have been a good thing to do... I only say in retrospect that Greenspan did the right thing in abandoning primary reliance on M2 during that period." While reaffirming that "I don't like operating through interest rates" and restating his confidence in longer-term moneyincome relationships, Friedman said that Greenspan had "done a very good job of threading his way through those [velocity] difficulties." This observation would be fleshed out in the thermostat hypothesis that Friedman championed in the 2000s.

\section{The Thermostat Hypothesis}

In 1966 Alan Walters, a U.K. monetarist, had observed that "If the [monetary] authority was perfectly successful then we should observe variations in the rate of change of the stock of money but not variations in the rate of change of

\footnotetext{
${ }^{55}$ Besides Monetary History, the books Friedman was referring to here were Friedman (1957) and Friedman and Friedman (1980).
} 
income...[a]ssuming that the authority's objective is to stabilize the growth of income." 56 The basic idea behind this statement is that if a variable $Y$ has a stochastic relationship with a variable $X$ that monetary policy can affect, a policy that stabilizes $Y$ will lead to fluctuations in $X$ to offset other potential sources of variation in $Y$. The result will be a low empirical correlation between $X$ and $Y$, despite the two enjoying a structural relationship.

A student of Friedman's, Levis Kochin, worked in the 1970s on the relevance of this idea for money-income relations, ${ }^{57}$ while Poole (1995) argued that roughly optimal policy since 1982 had produced low correlations between inflation and money growth.

Friedman initially showed little interest in ideas along these lines. He acknowledged in 1984 that successful stabilization should mean that "high monetary variability...[is] associated with low economic variability," but believed that the relevance of this was contradicted by the positive relationship between monetary variability and output (and nominal income) variability in the data. ${ }^{58}$ This was, of course, in line with his longheld position that stabilization policy had often been tried, but had proved counterproductive. Thus in 1967 Friedman had described the Federal Reserve's stated aim of responding to emerging economic conditions as "a formula guaranteed to produce bad policy" ( $N W, 01 / 09 / 67)$ and had written that forward-looking formulations of this approach were likely to be destabilizing, with policymakers "vainly trying to lean against next year's wind which, in the process, they are themselves stirring up" (WP, 11/05/67).

But by early 2000, however, in light of the much-reduced degree of output variability, Friedman had reached the view that stabilization policy had been executed successfully by the Federal Reserve in recent years and was a major reason for high M2 growth variability relative to output variability since 1992 (see Taylor, 2001). To articulate the idea, Friedman made an anal-

\footnotetext{
${ }^{56}$ Walters (1966, p. 276).

${ }^{57}$ Kochin (1973); see also Kishor and Kochin (2004).

${ }^{58}$ Friedman (1984a, p. 34).
}

ogy between successful stabilization policy and the behavior of a thermostat. This was a revival of an analogy prevalent in the 1950s; for example, a commentator on U.K. economic affairs, Anthony Crosland, wrote in 1956 that economic policy in practice would never achieve the ideal where "demand could be exactly set, as though by a thermostatic control, at just the right point."59 U.S. monetary policy in the 1990s, as Friedman saw it, had come closer to achieving the "thermostatic" ideal than many, including himself, had thought practicable.

Friedman was thus able to identify a period in which money growth targeting was inferior to the monetary policy actually pursued. He had always argued that this was possible in principle: Friedman (1960, p. 98) had said that there was "little to be said in theory" for a constant money growth rule and "persuasive theoretical grounds" for varying money growth "to offset other factors." Rather, the money growth rule recommendation emerged from the uncertainty underlying the policy responses required for successful stabilization, which meant that "deviations from the simple rule have been destabilizing rather than the reverse." Nor in later expositions did Friedman claim that money growth targeting was optimal in theory. ${ }^{60}$

There are some weaknesses in the thermostat hypothesis as an explanation for shifting moneyincome relations in the data. ${ }^{61}$ For his part, Friedman advanced the thermostat story only to account for some of the looseness in money-

\footnotetext{
${ }^{59}$ Crosland (1956, p. 398). Similarly, Warburton (1953, p. 10), in commenting on activist rules that Friedman had advanced in the 1940 s, said that they were designed to be "a self-regulating mechanism, such as a thermostat..."

${ }^{60}$ For example, in Friedman (1970b, pp. 18-19) the money growth rule was acknowledged as inferior in principle to "deliberate changes in the rate of monetary growth...to offset other forces," this alternative being rejected by Friedman "until such time as we demonstrably know enough to limit discretion by [using] more sophisticated rules." While usually made with nominal income stabilization as the implicit criterion, this conclusion was also applied to direct targeting of prices (or inflation) by Friedman (1968b, 1982b).

${ }^{61}$ For example, it does not distinguish between weak correlations that emerge because policymakers make use of a stable structural relationship between money and the economy and the case where much of the weakness reflects the fact that the structural relationship is itself undergoing change.
} 
income relations on quarterly data; he continued to believe that longer-period stability in nominal income required moderate rather than high variability in money.

\section{1st Century Developments}

The U.S. stock market peaked in early 2000 . Friedman attributed some of the stock market's strength to higher M2 growth (WSJ, 01/22/02; Friedman, 2005). Nevertheless, he concurred that stock prices had far exceeded economically justified values (FORB, 05/03/99). Thus, Friedman noted in October 2001, the Federal Reserve faced the issue of what to do in the aftermath of an "excessively bullish stock market" (UPI, 10/09/01).

"The monetary policy Greenspan is following I think really has no precedent," Friedman remarked on this occasion, adding that he had a "great deal of sympathy" with the interest-rate cuts that Greenspan had initiated in January 2001. Whether these cuts were sufficient, Friedman said, depended on "what their effect has been on monetary growth," though Friedman cautioned that money growth would now be difficult to interpret because "there's no doubt one of the effects of September 11 will be to increase the demand for cash balances" (UPI, 10/09/01). ${ }^{62}$ Four years later, Friedman (2005) reached a favorable verdict on the period. He maintained that monetary policy behavior, by keeping M2 growth high in the wake of the stockmarket decline, had stopped the equity price collapse from leading into anything more than a shallow recession. The monetary stimulus had also been withdrawn at "just about the rate required for a rapidly growing non-inflationary economy" (WSJ, 04/07/05).

\section{STILL A MONETARIST: 2002-06}

In June 2003 a profile appeared in a Financial Times magazine supplement that included brief remarks from Friedman on monetary targeting:

\footnotetext{
62 The powerful effect of national emergencies in increasing the demand for real money balances (equivalently, reducing velocity) was a long-standing Friedman theme (e.g., Friedman and Schwartz, 1963, pp. 673-75; Friedman and Schwartz, 1982, pp. 4, 228; Friedman, 1984b, p. 399).
}

"The use of quantity of money as a target has not been a success. I'm not sure I would as of today push it as hard as I once did" (FT, 06/07/03). To readers of Friedman's interviews in 1998-2000 with Barrons and John Taylor, the 2003 quotations were not a great surprise. Friedman had previously made it clear that he had been unhappy with how monetary targeting had typically been implemented in practice and had been impressed by how U.S. monetary policy in recent years had done better on economic stabilization than he had thought practicable and outperformed what he would expect from a money growth rule. The 2003 remarks were not a break with his position in these earlier interviews.

Some commentators, however, took the remarks in isolation and interpreted the 2003 interview as repudiation by Friedman of monetarism. ${ }^{63}$ William Keegan, the economics editor of the London Observer and a longtime critic of Friedman's, used the quote as the basis for an article entitled "So Now Friedman Says He Was Wrong" and asserted that "Friedman, now 91 [sic; 90], ... feel[s] it is time to own up. It is 'true confession' time" (OBS, 06/22/03). In light of this and similar "spins" on his remarks, Friedman decided to produce a lengthy exposition of his interpretation of the monetary policy developments in the preceding 15 years. The resulting article, in the Wall Street Journal, would disappoint anyone looking for confirmation that he had turned his back on monetarism. On the contrary, while again praising recent policy for doing better than a constant money growth rule, Friedman maintained the following position: "Velocity is ordinarily very stable, fluctuating

\footnotetext{
${ }^{63}$ Over the years, discussions of Friedman often seized on new public statements of his and alleged that these amounted to recanting of previous positions. For example, a commentator reacting to a talk Friedman gave in 1981 wrote, "Milton Friedman has made a significant change in his doctrine since his previous visit to Australia in 1975" (SML, 04/19/81). And in 1987 John Kenneth Galbraith said in an interview, "I think Professor Friedman, who was an interesting man, has disappeared into the shadows very much. He has accused the Reagan Administration of prime incompetence in the managing of economic policy" (SMH, 02/24/87). These claims of reversals in position, like those made in 2003, were unfounded-consisting either of incorrect readings of Friedman's earlier statements or illegitimate extrapolations from his later ones. Nevertheless, as we have seen, Friedman did change his position on certain issues, such as the relative merits of M1 and M2, and on the lag between monetary actions and inflation.
} 
only mildly...The $M V=P y$ key to a good thermostat was there all along” (WSJ, 08/19/03). Indeed, at the time that he was working on this article, Friedman noted to the present author:

In my original support for a straight money target, I always emphasized that it was partly a case based on ignorance, based on the fact that we really did not understand sufficiently well the detailed relationship between money, income, interest rates, and the like to be able to fine-tune, that our goal should be to develop a detailed enough understanding so that we could do better than a simple constant monetary growth target.

However, I believe still, as I did then, that constant monetary growth would produce a highly satisfactory price path, and, if it enabled you to get rid of the Federal Reserve System, that gain would compensate for sacrificing the further improvement that a more sophisticated rule could produce. ${ }^{64}$

Friedman also took the opportunity of the Wall Street Journal article to offer a story about why monetary policy had changed since the inflationary 1960s and 1970s. Over the yearsin interviews he gave in the late 1980s (e.g., FT, 02/23/87; $S F C, 08 / 18 / 87$ ) and even as late as 2000 (in the Taylor interview)—Friedman had appealed to far-fetched and unconvincing explanations for why policymakers had shifted to low inflation. These stories centered on the political profitability of inflation having been reduced by indexation of tax brackets and government securities. Accounts such as this attributed too much knowledge to pre-1980s policymakers regarding how to control inflation.

Now, instead, Friedman returned to themes that he had put forward during the 1970s and early 1980s, which emphasized the errors in policymakers' basic theories of inflation. In 2002 he noted that policymakers in the United States and United Kingdom "used to say inflation was caused by trade union power, cost pressures, and so on; nobody talks like that any more." 65 His 2003 article elaborated on this "shift in the theoretical

\footnotetext{
${ }^{64}$ Milton Friedman, email to author, July 21, 2003.

${ }^{65}$ Quoted in Pringle (2002, p. 15).
}

paradigm." The major change since the 1970s, Friedman now affirmed, was the shift by policymakers from adherence to cost-push views to acceptance that inflation was a monetary phenomenon (WSJ, 08/19/03). While pleased with this development, Friedman was unhappy with the fact that focus on monetary aggregates had receded. Always ready with an analogy, Friedman had written in 1966 that discussing monetary policy without mentioning money was like writing a book about love without mentioning sex. ${ }^{66}$

As far as current economic developments were concerned, in 2003 Friedman dismissed "all the talk about deflation." 67 A necessary condition for deflation, monetary contraction, had not occurred. As for whether falling high-tech goods prices could produce deflation, Friedman had dismissed this back in 1978: "The high price of cars doesn't cause inflation any more than a drop in the price of hand calculators causes deflation" (TDN, 05/19/78).

In December 1986 Friedman, while acknowledging some discomfort at being better known for the likes of Free to Choose than for his monetary economics, had foreshadowed that his research output would dry up-“people's capacities to do scientific work decline with age" (SFC, 12/26/86). As things turned out, he never could stop completely, and almost 20 years later, in August 2006, Friedman (now age 94) was putting the finishing touches on his latest research paper. Friedman delivered the paper to the London, Ontario, conference by videolink from San Francisco on August 18. The subject was tradeoffs in monetary policy, and the paper was a contribution to a Festschrift for Friedman's former student David Laidler. As noted above, Friedman had used the thermostat hypothesis to help explain recent money/income patterns. That hypothesis was based on the observation that M2 variability was high relative to output variability during the 1990s. But in reviewing the longer picture using annual data, Friedman now stressed that the larger event was the large reduction in the absolute level of M2 growth variability in recent decades.

\footnotetext{
${ }^{66}$ Friedman (1966, p. 24).

${ }^{67}$ Milton Friedman, email to author, July 21, 2003.
} 


\section{Figure 1}

\section{Fourteen-Quarter Moving Standard Deviation of Quarterly Annualized M2 Growth}

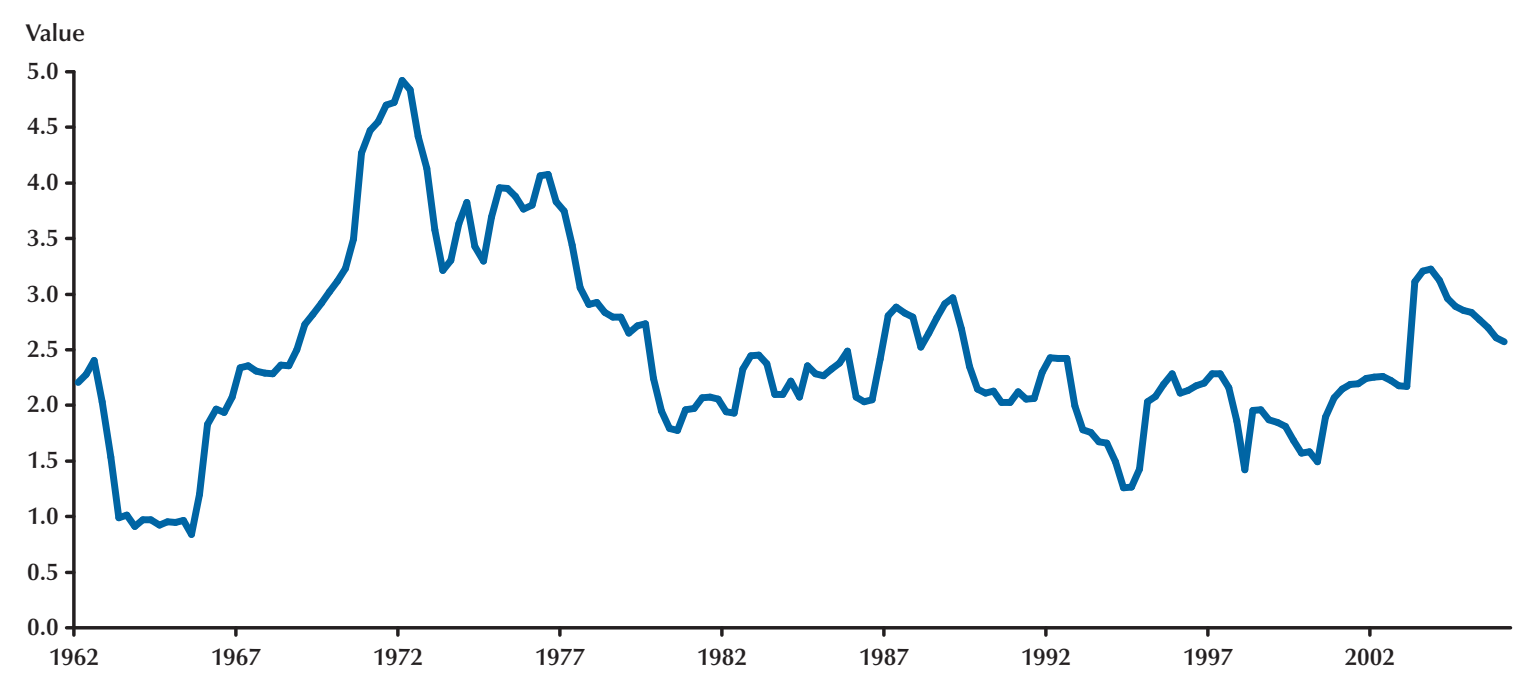

NOTE: The figure is based on quarterly averages of FRED data for seasonally adjusted M2. Before calculating growth rates and standard deviations, post-1982 observations on M2 were rescaled using the ratios implied by Friedman's (1988, p. 240) adjustment for the introduction of money market deposit accounts. This shift is also found to be important by Small and Porter (1989, p. 253) and Moore, Porter, and Small (1990, pp. 59-60), and their estimate of its magnitude is similar to Friedman's estimate.

(This is also evident in quarterly data: Figure 1 displays the 14-quarter standard deviation of money growth, a key statistic in the FriedmanModigliani [1977] debate.) "The collapse of the variability of output," Friedman wrote, "is clearly an effect of the collapse of monetary variability. In my opinion, the same results could have been obtained at any earlier time and can continue to be achieved in the future." 68

\section{CONCLUSION}

Despite his prolific writing, Milton Friedman did not provide a single, detailed record of his views on post-1960 U.S. monetary history. He instead relayed those views in a number of forums, including regular and semi-regular newspaper and magazine columns, books and articles, congressional testimony, and interviews with economists and the national and world media. The

\footnotetext{
${ }^{68}$ Friedman (2006).
}

objective of this paper has been to bring together, using archival material from several countries, information about Friedman's views and predictions regarding post-1960 U.S. monetary developments and to evaluate his interpretations in light of subsequent events. The 1960s and 1970s were notable for policymaker resistance to, then acceptance of, Friedman's consistently held views on exchange rates and on the control of inflation. Probably the most important changes in Friedman's outlook over the 1980s, 1990s, and 2000s were a firming of his preference for M2 as the definition of money, following several years of forecast errors using M1, and his concession that stabilization policy in the United States since the mid-1980s had been more successful than he had thought possible. Friedman's outlook nevertheless remained monetarist, and he continued to advocate a fixed money growth rule, arguing that such a constraint on policymaking was desirable.

In addition to giving an impression of Friedman's perspective on monetary policy 
practice, this analysis must shed some light on Friedman's theoretical framework, since, as he once said, there is always a "general economic model which each of us must have, underlying our specific temporal predictions."69

\section{REFERENCES}

Anderson, Richard G. and Kavajecz, Kenneth A. "A Historical Perspective on the Federal Reserve's Monetary Aggregates: Definition, Construction and Targeting." Federal Reserve Bank of St. Louis Review, March/April 1994, 76(2), pp. 1-31.

Bernanke, Ben S. “The Great Moderation.” Remarks at the meetings of the Eastern Economic Association, Washington, DC, February 20, 2004.

Bernanke, Ben S.; Laubach, Thomas; Mishkin, Frederic S. and Posen, Adam S. Inflation Targeting: Lessons from the International Experience. Princeton, NJ: Princeton University Press, 1999.

Blanchard, Olivier J. and Simon, John. "The Long and Large Decline in U.S. Output Volatility." Brookings Papers on Economic Activity, 2001, 32(1), pp. 135-64.

Blinder, Alan S. "Changes in the Financial System: Implications for Monetary Policy: Comments and Discussion.” Brookings Papers on Economic Activity, 1984, 15(1), pp. 266-72.

Blinder, Alan S. "Distinguished Lecture on Economics in Government: What Central Bankers Could Learn from Academics—and Vice Versa." Journal of Economic Perspectives, Spring 1997, 11(2), pp. 3-19.

Brookings Institution. "General Discussion: Innovations and Monetary Control." Brookings Papers on Economic Activity, 1981, 12(1), pp. 190-99.

Burns, Arthur F. "Letter on Monetary Policy.” Federal Reserve Bank of St. Louis Review, November 1973, 55(11), pp. 15-22.

Crosland, C.A.R. The Future of Socialism. New York: Macmillan, 1956.

${ }^{69}$ Milton Friedman, interview with the author, Stanford University, January 22, 1992.
Darby, Michael R.; Friedman, Milton; Poole, William; Lindsey, David E. and Bazdarich, Michael J. "Recent Behavior of the Velocity of Money." Contemporary Policy Issues, January 1987, 5(1), pp. 1-33.

Despres, Emile; Hart, Albert G.; Friedman, Milton; Samuelson, Paul A. and Wallace, Donald H. "The Problem of Economic Instability," American Economic Review, September 1950, 40(4), pp. 505-38.

Erceg, Christopher and Levin, Andrew T. "Imperfect Credibility and Inflation Persistence." Journal of Monetary Economics, May 2003, 50(4), pp. 915-44.

Frazer, William. Power and Ideas: Milton Friedman and the Big U-Turn. Gainesville, FL: Gulf-Atlantic, 1988.

Friedman, Benjamin M. "Lessons on Monetary Policy from the 1980s." Journal of Economic Perspectives, Summer 1988, 2(3), pp. 51-72.

Friedman, Milton. A Theory of the Consumption Function. Princeton: Princeton University Press, 1957.

Friedman, Milton. A Program for Monetary Stability. Fordham, NY: Fordham University Press, 1960.

Friedman, Milton. "Statement and Testimony (March 3, 1964)," in House Committee on Banking and Currency, Hearings on the Federal Reserve System after Fifty Years. Washington, DC: Government Printing Office, 1964, pp. 1133-78.

Friedman, Milton. "What Price Guideposts?” in G.P. Shultz and R.Z. Aliber, eds., Guidelines: Informal Controls and the Market Place. Chicago: University of Chicago Press, 1966, pp 17-39.

Friedman, Milton. Dollars and Deficits: Inflation, Monetary Policy and the Balance of Payments. Englewood Cliffs, NJ: Prentice Hall, 1968a.

Friedman, Milton. "The Role of Monetary Policy." American Economic Review, March 1968b, 58(1), pp. 1-17.

Friedman, Milton. "Comment on Tobin.” Quarterly Journal of Economics, May 1970a, 84(2), pp. 318-27. 
Friedman, Milton. "The Counter-Revolution in Monetary Theory." IEA Occasional Paper No. 33, 1970b. (Reprinted in M. Friedman, Monetarist Economics. London: Institute of Economic Affairs, 1991, pp. 1-20.)

Friedman, Milton. "Controls on Interest Rates Paid by Banks." Journal of Money, Credit, and Banking, February 1970c, 2(1), pp. 15-32.

Friedman, Milton. "Comments on the Critics." Journal of Political Economy, September/October 1972a, 80(5), pp. 906-50.

Friedman, Milton. "Have Monetary Policies Failed?" American Economic Review (Papers and Proceedings), May 1972b, 62(2), pp. 11-18.

Friedman, Milton. "Letter on Monetary Policy." Federal Reserve Bank of St. Louis Review, March 1974, 56(3), pp. 20-23.

Friedman, Milton. "Twenty-Five Years After the Rediscovery of Money: What Have We Learned? Discussion.” American Economic Review (Papers and Proceedings), May 1975, 65(2), pp. 176-79.

Friedman, Milton. "Nobel Lecture: Inflation and Unemployment." Journal of Political Economy, June 1977, 85(3), pp. 451-72.

Friedman, Milton. "Memorandum: Response to Questionnaire on Monetary Policy, June 11, 1980," in Treasury and Civil Service Committee, Memoranda on Monetary Policy. London: HMSO, 1980, pp. 55-61.

Friedman, Milton. "Monetary Policy: Theory and Practice." Journal of Money, Credit, and Banking, February 1982a, 14(1), pp. 98-118.

Friedman, Milton. "Letter to Roger W. Jensen, ViceChairman Economic Committee," in Joint Economic Committee, Monetarism and the Federal Reserve's Conduct of Monetary Policy: Compendium of Views Prepared for the Use of the Subcommittee on Monetary and Fiscal Policy. Washington, DC: Government Printing Office, 1982b, pp. 73-74.

Friedman, Milton. "Monetary Policy for the 1980s," in J.H. Moore, ed., To Promote Prosperity: U.S.
Domestic Policy in the Mid-1980s. Stanford, CA: Hoover Institution Press, 1984a, pp. 23-60.

Friedman, Milton. "Lessons from the 1979-82 Monetary Policy Experiment." American Economic Review (Papers and Proceedings), May 1984b, 74(2), pp. 397-400.

Friedman, Milton. "How to Give Monetarism a Bad Name," in J.K. Galbraith and Dan C. Roberts, eds., Monetarism, Inflation and the Federal Reserve. Washington, DC: Government Printing Office, 1985a, pp. 51-61.

Friedman, Milton. "Questions and Comments: Replies by Milton Friedman," in D.J. Theroux, ed., Politics and Tyranny: Lessons in Pursuit of Freedom. San Francisco: Pacific Institute for Public Policy Research, 1985b, pp. 37-46.

Friedman, Milton. "My Evolution as an Economist," in W. Breit and R.W. Spencer, eds., Lives of the Laureates: Seven Nobel Economists. Cambridge, MA: MIT Press, 1986, pp. 77-92.

Friedman, Milton. "Money and the Stock Market." Journal of Political Economy, April 1988, 96(2), pp. 221-45.

Friedman, Milton. "Preface," in A Program for Monetary Stability, 10th printing with new preface. Fordham, NY: Fordham University Press, 1992, pp. vii-xii.

Friedman, Milton. "A Natural Experiment in Monetary Policy Covering Three Episodes of Growth and Decline in the Economy and the Stock Market." Journal of Economic Perspectives, Fall 2005, 19(4), pp. 145-50.

Friedman, Milton. "Tradeoffs in Monetary Policy.” Unpublished manuscript, Hoover Institution, August 2006.

Friedman, Milton and Friedman, Rose D. Free to Choose. New York: Harcourt Brace Jovanovich, 1980.

Friedman, Milton and Friedman, Rose D. Two Lucky People: Memoirs. Chicago: University of Chicago Press, 1998. 


\section{Nelson}

Friedman, Milton and Modigliani, Franco. "Discussion of 'The Monetarist Controversy."' Federal Reserve Bank of San Francisco Economic Review, Spring Supplement 1977, 3(1), pp. 12-26.

Friedman, Milton and Schwartz, Anna J. A Monetary History of the United States, 1867-1960. Princeton: Princeton University Press, 1963.

Friedman, Milton and Schwartz, Anna J. Monetary Statistics of the United States. New York: Columbia University Press, 1970.

Friedman, Milton and Schwartz, Anna J. Monetary Trends in the United States and the United Kingdom: Their Relation to Income, Prices, and Interest Rates, 1867-1975. Chicago: University of Chicago Press, 1982.

Gordon, Robert J. "Comments on Franco Modigliani and Albert Ando," in J.L. Stein , ed., Monetarism. Amsterdam: North Holland, 1976, pp. 52-66.

Hammond, J. Daniel. Theory and Measurement: Causality Issues in Milton Friedman's Monetary Economics. Cambridge: Cambridge University Press, 1996.

Heller, Robert H.; Crockett, Andrew; Friedman, Milton; Niskanen, William A. and Sinai, Allen. "Economic Outlook." Contemporary Policy Issues, Fall 1984-1985, 3(1), pp. 15-52.

Kishor, Narayan Kundan and Kochin, Levis A. "The Success of the Fed and the Death of Monetarism." Unpublished manuscript, University of Washington, August 2004.

Kochin, Levis A. Judging Stabilization Policy. PhD thesis, Department of Economics, University of Chicago, 1973.

Krugman, Paul. "Who Was Milton Friedman?” New York Review of Books, February 15, 2007a, 54(2), pp. 27-30.

Krugman, Paul. "Paul Krugman Replies,” New York Review of Books, March 29, 2007b, 54(5), p. 50.

Laidler, David. "The Legacy of the Monetarist
Controversy.” Federal Reserve Bank of St. Louis Review, March/April 1990, 72(2), pp. 49-64.

Leeson, Robert. "Inflation, Disinflation and the Natural Rate of Unemployment: A Dynamic Framework for Policy Analysis," in D.W.R. Gruen, ed., The Australian Economy in the 1990s. Sydney: Reserve Bank of Australia, 2000, pp. 124-75.

McConnell, Margaret M. and Perez-Quiros, Gabriel. "Output Fluctuations in the United States: What Has Changed since the Early 1980's?" American Economic Review, December 2000, 90(5), pp. 146476.

Moore, George R.; Porter, Richard D. and Small, David H. "Modeling the Disaggregated Demands for M2 and M1: The U.S. Experience in the 1980s," in Peter Hooper et al., eds., Financial Sectors in Open Economies: Empirical Analysis and Policy Issues. Washington, DC: Board of Governors of the Federal Reserve System, 1990, pp. 21-105.

Nelson, Edward. "News-Magazine Monetarism," in P. Minford, ed., Money Matters: Essays in Honour of Alan Walters. Cheltenham, UK: Edward Elgar, 2004, pp. 123-47.

Orphanides, Athanasios. "The Road to Price Stability." American Economic Review (Papers and Proceedings), May 2006, 96(2), pp. 178-81.

Poole, William. "Monetary Policy Implications of Recent Changes in the Financial Systems of the United States and Europe," in K. Sawamoto, Z. Nakajima, and H. Taguchi, eds., Financial Stability in a Changing Environment. London: Macmillan, 1995, pp. 109-43.

Pringle, Robert. "Interview: Milton Friedman." Central Banking, 2002, 8(1), pp. 15-23.

Romer, Christina D. and Romer, David H.

"A Rehabilitation of Monetary Policy in the 1950's." American Economic Review (Papers and Proceedings), May 2002, 92(2), pp. 121-27.

Schwartz, Anna J. and Nelson, Edward. "Who Was Milton Friedman? A Response." New York Review of Books, March 29, 2007, 54(5), pp. 48-50. 
Simpson, Thomas D. "The Redefined Monetary Aggregates." Federal Reserve Bulletin, February 1980, 66(2), pp. 97-114.

Small, David H. and Porter, Richard D. "Understanding the Behavior of M2 and V2." Federal Reserve Bulletin, April 1989, 75(4), pp. 244-254.

Stock, James H. and Watson, Mark. "Has the Business Cycle Changed and Why?" NBER Macroeconomics Annual 2002, 17, pp. 159-218.

Taylor, John B. "An Interview with Milton Friedman.” Macroeconomic Dynamics, February 2001, 5(1), pp. 101-31.
Tobin, James. "Money and Income: Post Hoc Ergo Propter Hoc?" Quarterly Journal of Economics, May 1970, 84(2), pp. 301-17.

Ulam, Adam B. Dangerous Relations: The Soviet Union in World Politics, 1970-1982. Oxford: Oxford University Press, 1983.

Walters, Alan A. "Monetary Multipliers in the U.K., 1880-1962." Oxford Economic Papers, November 1966, 18(3), pp. 270-83.

Warburton, Clark. "Rules and Implements for Monetary Policy." Journal of Finance, March 1953, 8(1), pp. 1-21.

\section{APPENDIX A}

\section{Abbreviations for Periodicals Cited in Text}

BAR—Barrons (U.S.); BOOKN—Booknotes (CSPAN television program; transcript); CHA—Challenge (U.S.); CNN-Moneyline (CNN television program; transcript); CSM-Christian Science Monitor (Boston); CT_Chicago Tribune; DC—Daily Courier (Connellsville, PA); DFP—Detroit Free Press; DOMDominion Post (Morgantown, WV); DS—Der Spiegel (Hamburg, Germany); ESN_Edmonton Sun (Alberta, Canada); FEER_Far Eastern Economic Review (Hong Kong); FORB_Forbes magazine (U.S.); FORT_Fortune magazine (U.S.); FT_Financial Times (London); FUT_Futures (U.S.); IT_Irish Times (Dublin); JOH_The Star (Johannesburg, South Africa); JP_Jerusalem Post (Israel); JT_Japan Times (Tokyo); KCS—Kansas City Star (Kansas City, MO); LAT_Los Angeles Times; MHER—The Herald (Melbourne, Australia); MINN—Minneapolis Star-Tribune; NW—Newsweek (U.S.); NYDN—Daily News (New York); NYP—New York Post; NYT—New York Times; NZH—New Zealand Herald (Wellington); OAK-Oakland Tribune (Oakland, CA); OBS-The Observer (London); OKL-The Daily Oklahoman; PHB—Philadelphia Bulletin (Philadelphia, PA); PHI_Philadelphia Inquirer; SCMP—South China Morning Post (Hong Kong); SFC—San Francisco Chronicle; SLGD—St. Louis Globe-Democrat; SMHSydney Morning Herald; SML—Sunday Mail (Brisbane, Australia); STE—Sunday Telegraph (London): STR_Straits Times (Singapore); TDN_The Detroit News; TG_The Guardian (London and Manchester, U.K.); TIME_Time magazine (U.S.); TSN_Toronto Sun (Ontario, Canada); TST_Toronto Star (Ontario, Canada); TT_The Times (London); UPI-UPI news wire; USAT_USA Today; USNR-U.S. News and World Report; WCPD—Weekly Compilation of Presidential Documents (Washington, DC); WPWashington Post; WSJ-Wall Street Journal (New York). 
APPENDIX B

\section{Chronological List of Media Articles Referred to in Text}

‘Lex’, “A Prosperous New Year? Equities v. Gilts for 1963,” Financial Times, December 29, 1962, p. 1.

David R. Francis, “The Economic Scene,” Christian Science Monitor, September 28, 1964, p. 10.

David M. Grebler, “Rate Hike Hailed by Top Economist,” St. Louis Globe-Democrat, December 9, 1965.

Paul A. Samuelson, "The New Economics in the U.S. Faces Some Old Problems," Financial Times, December 31, 1965, p. 9.

“Quotable,” Chicago Tribune, May 8, 1966, p. G5.

Richard L. Strout, "Jiggle That Jolted Economists," Christian Science Monitor, December 19, 1966, pp. 1 and 7.

Milton Friedman, “Current Monetary Policy,” Newsweek, January 9, 1967.

Milton Friedman, “Current Monetary Policy,” Newsweek, October 30, 1967.

Milton Friedman, “Taxes, Money and Stabilization,” Washington Post, November 5, 1967, pp. H1 and H3.

(Also appeared in The Banker (London), December 1968, pp. 1096-101.)

Louis Dombrowski, “Ask Money Supply Equal to Growth Rate,” Chicago Tribune, July 5, 1968, p. C8.

Paul Samuelson, “Don’t Make Too Much of the Quantity Theory,” Sunday Telegraph, December 15, 1968,

pp. 19 and 21.

“The New Attack on Keynesian Economics,” Time, January 10, 1969.

Milton Friedman, “Monetary Overkill,” Newsweek, August 18, 1969.

Albert L. Kraus, “'Mini-Recession’ Seen,” Dominion Post, August 24, 1969, p. 3D.

Milton Friedman, “A New Chairman at the Fed,” Newsweek, February 2, 1970.

Vera Glaser, “Economist Hits Burns on Inflation Plan,” Philadelphia Inquirer, May 29, 1970.

John Maclean, “Fewer Jobs, Product Dip Called Vital,” Chicago Tribune, June 29, 1970, p. E7.

Rob Warden, “What Really Causes Inflation?” Chicago Daily News, July 29, 1970, pp. 3 and 4.

Arthur Greenspan, “Leading Economists View Nixon Freeze,” New York Post, August 16, 1971, pp. 5 and 39.

UPI, “Bretton Woods System Is Dead, Friedman Says,” Japan Times, September 24, 1971, p. 13.

Milton Friedman, “The Fed on the Spot,” Newsweek, October 16, 1972, p. 98.

Associated Press, “Economist Says Controls to Stay,” Kansas City Star, December 7, 1972, p. 2A. 
John Getze, “Managing Economy: Fed Hung on Horns of Dilemma,” Los Angeles Times, February 18, 1973, pp. G1 and G3.

Leonard Wiener, “Freeze 'Worst Mistake,”' Oakland Tribune, June 15, 1973, p. F17.

Milton Friedman, “The Hard Truth,” Newsweek, September 17, 1973.

““Good Chance of Recession,’ Milton Friedman Declares,” Philadelphia Bulletin, October 12, 1973.

UPI, “FRB’s Burns Favors Wage, Price Curbs,” Japan Times, October 15, 1973, p. 12.

“Facing Inflation-Interview: Milton Friedman,” Challenge, November/December 1973, pp. 29-37.

A. Joseph Newman Jr., “Free-Enterprise Answer to Energy Woe,” Philadelphia Bulletin, November 9, 1973.

Nick Poulos, “Political Climate Key to Greenspan Future,” Chicago Tribune, July 17, 1974, p. C7.

Robert Betts, “Experts Debate Cures for Inflation,” Daily Courier, August 16, 1974, p. 10.

Frances Cairncross, “Inflation 'Immoral Tax No M.P. Would Approve,”, The Guardian, September 16, 1974 , p. 12.

Press Association, “Inflation a Threat to Democracy-U.S. Economist,” Irish Times, September 18, 1974, p. 14.

Milton Friedman, “Who Represents Whom?” Newsweek, October 14, 1974.

Leonard Silk, “Money Growth a Puzzle,” New York Times, February 26, 1975, p. 53.

Dennis V. Waite, “A Monetarist Talks Tough on Recession,” Philadelphia Bulletin, March 2, 1975.

Milton Friedman, “Six Fallacies,” Wall Street Journal, June 30, 1975, p. 11.

Milton Friedman, “Five Examples of Fed Double-Talk,” Wall Street Journal, August 21, 1975, p. 6.

Milton Friedman, “How to Hit the Money Target,” Newsweek, December 8, 1975.

Associated Press, “Ford Promotes Speech Writer,” The Detroit News, February 5, 1976.

Associated Press, “U.S. Savings Bonds Called Ripoff,” Oakland Tribune, February 12, 1976, p. 1.

Neil Behrmann, “Friedman Doubts Quick U.S. Recovery,” The Star, April 5, 1976, p. 20.

“Friedman Takes Stanford Post,” Chicago Tribune, November 2, 1976, p. C11.

UPI, “Friedman to Be Research Fellow at Stanford's Hoover Institution,” New York Times, November 3, 1976, p. 23.

Louis Rukeyser, “A ‘Conservative’ Carter Predicted,” Philadelphia Bulletin, November 15, 1976.

Jerome Idaszak, “Friedman Says We Asked for Inflation,” Philadelphia Bulletin, November 18, 1976.

Milton Friedman, “To Jimmy from James,” Newsweek, December 6, 1976, p. 45. 


\section{Nelson}

“Names and Faces,” Detroit Free Press, December 25, 1976, p. 15A.

Milton Friedman, "Behind the Unemployment Numbers,” Newsweek, February 7, 1977, p. 63.

"Where Carter Is Going Wrong: Interview with Nobel Prize Winner Milton Friedman," U.S. News and World Report, March 7, 1977, p. 20.

Milton Friedman, “Why Inflation Persists,” Newsweek, October 3, 1977.

Donald C. Bauder, “Economist Assails Growth in Monetary Aggregates,” St. Louis Globe-Democrat, December 7, 1977.

David M. Grebler, “Friedman Is Optimistic About Public’s Economic Understanding,” St. Louis Globe-Democrat, December 16, 1977.

Milton Friedman, “Inflationary Recession,” Newsweek, April 24, 1978, p. 81.

Walter B. Smith, “Take Mild Recession Now, or Worse Later, Economist Forecasts,” The Detroit News, May 19, 1978.

AAP, “Economist Points to U.S. Recession,” The Herald, May 22, 1978, p. 20.

Milton Friedman, “Money Watchers Beware,” Newsweek, October 30, 1978, p. 62.

Milton Friedman, “Volcker’s Inheritance,” Newsweek, August 20, 1979.

Timothy C. Gartner, “Why Americans 'Like Inflation,”’ San Francisco Chronicle, October 18, 1979 , p. 31.

Milton Friedman, “Our New Hidden Taxes,” Newsweek, April 14, 1980.

Milton Friedman, “Monetary Overkill,” Newsweek, July 14, 1980.

Milton Friedman, “Marx and Money,” Newsweek, October 27, 1980.

Colin Larsen, “Friedman Advises 'Don’t Blame the Politicians for Everything,'” New Zealand Herald, April 18, 1981, p. 12.

H.W. Herbert, “A Change in Milton Friedman,” Sunday Mail, April 19, 1981, p. 22.

Glen Bayless, “Economist Raps Federal Reserve,” Daily Oklahoman, May 19, 1981, p. 86.

Harrison Rainie and James A. White, “Friedman: Kill the Fed,” Daily News, May 22, 1981, p. 38.

Milton Friedman, “Reaganomics and Interest Rates,” Newsweek, September 21, 1981, p. 27.

Ronald Reagan, "Remarks and a Question-and-Answer Session at a Working Luncheon with Out-of-Town Editors, October 16, 1981,” Weekly Compilation of Presidential Documents transcript; www.presidency.ucsb.edu.

Wolfgang Kaden and Walte Knips, “Das Ganze Sozialsystem Ist Falsch’: Der Ökonomie-Nobelpreisträger Milton Friedman über die Amerikanische und Britische Wirtschaftspolitik,” Der Spiegel, January 18, 1982, pp. 109-16. 
Milton Friedman, “The Yo-Yo Economy,” Newsweek, February 15, 1982.

“Friedman Predicts Fall in Inflation Rate to 6pc,” Straits Times, February 19, 1982.

Milton Friedman, “An Aborted Recovery?” Newsweek, August 23, 1982.

Bjorn Tretvoll, “Oil Could Fall to US\$10 a Barrel-Friedman,” South China Morning Post, September 17, 1982, p. B8.

Maxwell Newton, “Hokum Marks Fed Policy Switch,” New York Post, October 12, 1982.

Peter Brimelow, “Economics’ Latest Messiah,” Edmonton Sun, October 21, 1982, p. 11.

Milton Friedman, “The Needle Got Stuck,” Newsweek, July 25, 1983, p. 4.

UPC, “Top Economist Predicts: More Inflation in '84,” Toronto Sun, August 30, 1983.

Milton Friedman, “Why a Surge of Inflation Is Likely Next Year,” Wall Street Journal, September 1, 1983 , p. 24.

Thomas C. Hayes, “Reagan Preoccupies Economic Meeting,” New York Times, December 31, 1983, pp. $29-30$.

Walter Guzzardi Jr., “The Dire Warnings of Milton Friedman,” Fortune, March 19, 1984, pp. 20-25.

Michael Quint, “Money Data Backed as Gauge,” New York Times, April 30, 1984, p. D7.

Lindley H. Clark, Jr. and Laurie McGinley, "Money’s Role: Monetarists Succeed in Pushing Basic Ideas But Not Their Policies,” Wall Street Journal, December 10, 1984, pp. 1 and 16.

Gerald M. Connors, “Some Good Things Do Last,” Daily News, November 13, 1985, p. 58.

Daniel Rosenheim, “Sprinkel Questions Reliability of M1,” San Francisco Chronicle, July 4, 1986, p. 33.

Milton Friedman, “M1’s Hot Streak Gave Keynesians a Bad Idea,” Wall Street Journal, September 18, 1986, p. 32.

Jonathan Peterson, “Defining Friedman Takes a Lifetime,” San Francisco Chronicle, December 26, 1986, pp. 39 and 41 .

Milton Friedman, “Monetary History, Not Dogma,” Wall Street Journal, February 12, 1987, p. 24.

Anatole Kaletsky, “Freedom Rules, OK: Anatole Kaletsky Talks to Milton Friedman, Father of Monetarism,” Financial Times, February 23, 1987, p. 12.

Kenneth Davidson, “J.K. Galbraith and the New Economics,” Sydney Morning Herald, February 24, 1987, p. 15.

Mike Meyers, “Fed Chairman Wields Power by Influence,” Minneapolis Star-Tribune, June 3, 1987.

“Milton Friedman Says He’d Dump the Fed,” San Francisco Chronicle, June 8, 1987, p. 23.

Maxwell Newton, “U.S. Notebook: Economic Figures Knock the Optimism,” The Times, July $20,1987$.

Arthur M. Louis, “Milton Friedman Optimistic on Long-Term Inflation,” San Francisco Chronicle, August 18, 1987 , p. 52. 


\section{Nelson}

Daniel Doron, “'Is the Private Sector Really Privatized?': Part Five of an Interview with Prof Milton Friedman,” Jerusalem Post, November 11, 1987.

Milton Friedman, “Money and Economy: The Twain Do Meet,” Wall Street Journal, June 22, 1988, p. 25.

Louis Rukeyser, “Economist Friedman Gives High Praise to Greenspan,” Toronto Star, March 11, 1989, p. B2.

Milton Friedman, “Whither Inflation?” Wall Street Journal, July 5, 1989.

Otto Friedrich, “Freed From Greed?” Time, January 1, 1990.

Debra Sherman, “Nobel Laureate Discounts Impact of War on U.S. Economy,” Futures, March 1, 1991, p. 56H.

Milton Friedman, “Too Tight for a Strong Recovery,” Wall Street Journal, October 23, 1992, p. A12.

Milton Friedman, “The Second Industrial Revolution,” Far Eastern Economic Review, October 28, 1993, p. 23.

Brian Lamb, "Interview with Milton Friedman: Introduction to the Fiftieth Anniversary Edition of F.A. Hayek's Road to Serfdom," Booknotes (CSPAN television program), telecast November 20, 1994 (transcript).

Milton Friedman, “Getting Back to Real Growth,” Wall Street Journal, August 1, 1995, p. A14.

Lou Dobbs, "IMF Bailout: Interview with Milton Friedman,” Moneyline (CNN television program), telecast January 23, 1998 (transcript).

Gene Epstein, “Mr. Market: A Nobelist Views Today’s Fed, Currencies, Social Security, Regulation,” Barron’s, August 24, 1998, p. 30.

Peter Brimelow, "Bubblenomics,” Forbes, May 3, 1999, p. 138.

Ian Campbell, “Friedman Opposes Stimulus Package,” UPI, October 9, 2001.

Milton Friedman, “Follow the Money,” Wall Street Journal, January 22, 2002.

Simon London, "Lunch with the FT-Milton Friedman: The Long View," Financial Times (Financial Times

Magazine supplement, Issue No. 7), June 7, 2003, pp. 12-13; ft.com: June 5, 2003.

William Keegan, “So Now Friedman Says He Was Wrong,” The Observer, June 22, 2003, Business section, p. 7.

Milton Friedman, “The Fed’s Thermostat,” Wall Street Journal, August 19, 2003, p. A8.

Milton Friedman, “No Cause to Berate Fed for 'Reigniting Inflation,”' Wall Street Journal, April 7, 2005.

Bill Nichols and Tom Vanden Brook, “Tributes Pour In for Ford,” USA Today, December 27, 2006, pp. 1A-2A. 